\title{
"When We're on the Ice, All We Have is Our Inuit Qaujimajatuqangit": Mobilizing Inuit Knowledge as a Sea Ice Safety Adaptation Strategy in Mittimatalik, Nunavut
}

\author{
Katherine J. Wilson, ${ }^{1,2}$ Andrew Arreak, ${ }^{3}$ Jamesie Itulu, ${ }^{4}$ Sikumiut Community Management Committee, ${ }^{5}$ \\ Gita J. Ljubicic ${ }^{6}$ and Trevor Bell ${ }^{1}$
}

(Received 1 February 2021; accepted in revised form 11 May 2021)

\begin{abstract}
Increased variability in weather and sea ice conditions due to climate change has led to high rates of injury, trauma, and death for Inuit travelling on the sea ice. Contributing to these high rates are the ongoing effects of colonial policies that diminish and disrupt the intergenerational transfer of sea ice Inuit Qaujimajatuqangit (IQ). Despite these challenges, place-based experiential IQ continues to be the most important information source for safe travel on the sea ice. This paper presents an Inuit-led, coproduced, cross-cultural research project in which Inuit youth documented and mobilized sea ice IQ in Mittimatalik (Pond Inlet), Nunavut for safe community sea ice travel. We outline the Inuit youth training to facilitate the terminology and participatory mapping workshops and to document this IQ. We also discuss the IQ that was most important to share, and the mapping and artistic methods used to mobilize this IQ into a booklet, maps, and posters. Inuktitut sea ice terms are the foundation to enable youth with the skills to learn about sea ice IQ with experienced hunters. IQ enables Inuit to interpret and synthesize information from weather forecasts, earth observations, and community-based monitoring to apply to local conditions. Seasonal IQ maps of safe and hazardous sea ice conditions provide travel planning information at spatial and temporal scales that supplemental information sources cannot address. The IQ products mobilize preparedness, situational awareness, navigation, and interpretation skills so Inuit youth can become more self-reliant, as access to technology is not always possible once out on the sea ice.
\end{abstract}

Key words: Inuit Qaujimajatuqangit; knowledge mobilization; sea ice travel safety; climate change adaptation; Inuit self-determination in research

RÉSUMÉ. La fluctuation accrue des conditions météorologiques et de l'état de la glace de mer découlant du changement climatique se traduit par des taux plus élevés de blessures, de traumatismes et de décès chez les Inuits se déplaçant sur la glace de mer. À cela s'ajoutent les effets permanents des politiques coloniales qui amenuisent et perturbent le transfert intergénérationnel de l'Inuit Qaujimajatuqangit (IQ) au sujet de la glace de mer. Malgré ces défis, l'IQ tiré de l'expérience sur les lieux continue de représenter la source d'information la plus importante pour favoriser des déplacements sécuritaires sur la glace de mer. Cet article présente un projet de recherche interculturel dirigé et co-réalisé par des Inuits dans le cadre duquel de jeunes Inuits ont documenté et mobilisé l'IQ sur la glace de mer à Mittimatalik (inlet Pond), au Nunavut, en vue de déplacements communautaires sécuritaires sur la glace de mer. Nous mettons l'accent sur la formation reçue par les jeunes Inuits visant à faciliter les ateliers de terminologie et de cartographie participative ainsi qu'à documenter l'IQ en question. Nous discutons également de l'IQ le plus important à partager de même que de la cartographie et des méthodes artistiques utilisées pour mobiliser l'IQ dans un cahier, sur des cartes et sur des affiches. Les termes inuktituts propres à la glace de mer servent de fondement pour doter les jeunes des connaissances nécessaires pour apprendre l'IQ de la glace de mer avec les chasseurs d'expérience. L'IQ permet aux Inuits d'interpréter et de synthétiser l'information en provenance des prévisions météorologiques, des observations de la terre et de la surveillance communautaire afin de l'appliquer aux conditions locales. Les cartes saisonnières de l'IQ illustrant les conditions sécuritaires et les conditions dangereuses de la glace de mer fournissent de l'information pour la planification des déplacements à l'échelle spatiale et temporelle que des sources supplémentaires ne pourraient fournir. Les produits de l'IQ permettent de mobiliser les compétences en préparation, en connaissance de la situation, en navigation et en interprétation pour que les jeunes Inuits puissent devenir plus autonomes, car l'accès à la technologie n'est pas toujours possible lorsqu'ils se trouvent sur la glace de mer.

\footnotetext{
${ }^{1}$ Department of Geography, Memorial University of Newfoundland; 231 Elizabeth Avenue, St. John's, Newfoundland and Labrador A1C 5S7, Canada

${ }^{2}$ Corresponding author: Katherine.Wilson@mun.ca

${ }^{3}$ Nunavut Operations Lead for Qikiqtaaluk North, SmartICE Sea Ice Monitoring \& Information Inc., Mittimatalik, Nunavut X0A 0S0, Canada

${ }^{4}$ Jamesie Itulu; Borealis Ink; Mittimatalik, Nunavut X0A 0S0, Canada

${ }^{5}$ Sikumiut Community Management Committee, Mittimatalik, Nunavut X0A 0S0, Canada

${ }^{6}$ School of Earth, Environment and Society, McMaster University; 1280 Main Street West, Hamilton, Ontario L8S 4K1, Canada

(C) The Arctic Institute of North America
} 
Mots clés : Inuit Qaujimajatuqangit; mobilisation des connaissances; sécurité des déplacements sur la glace de mer; adaptation au changement climatique; autodétermination des Inuits dans la recherche

Traduit pour la revue Arctic par Nicole Giguère.

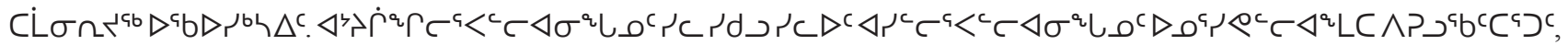

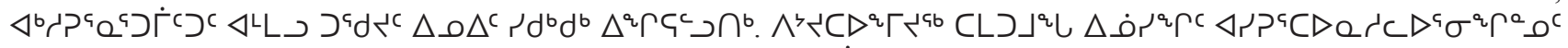

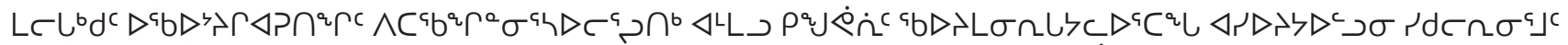

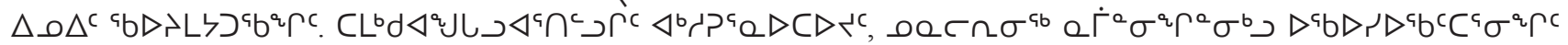

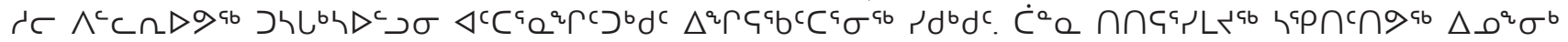

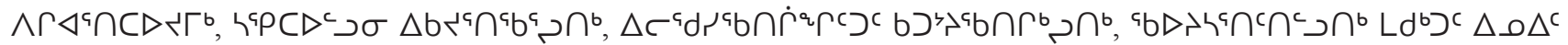

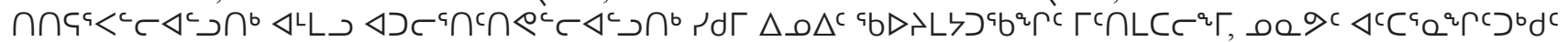

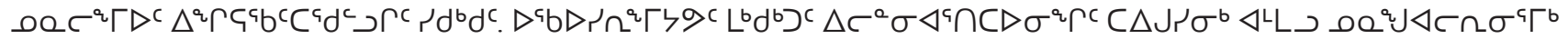

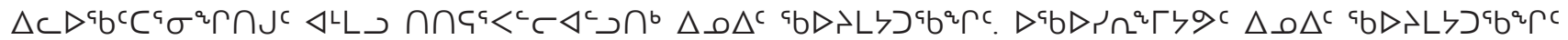

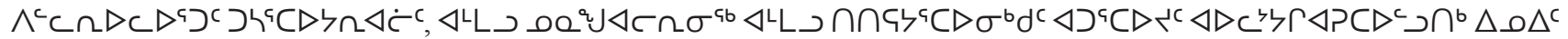

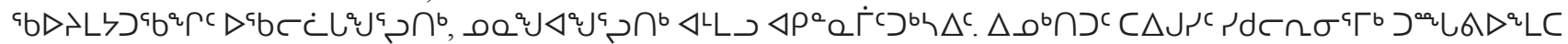

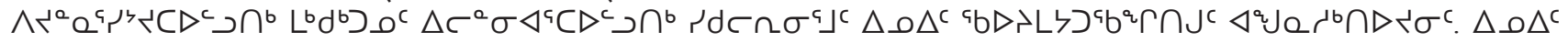

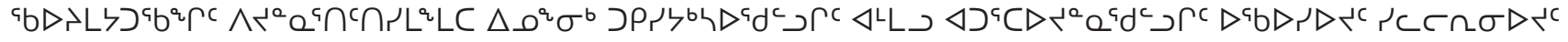

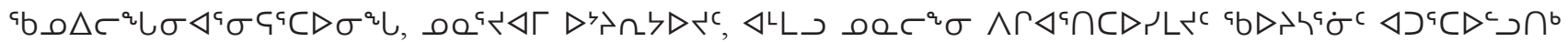

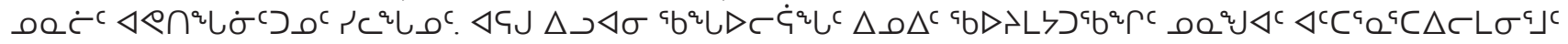

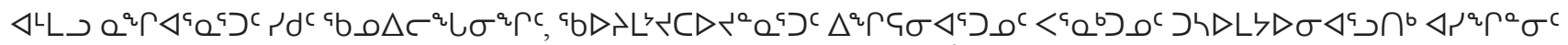

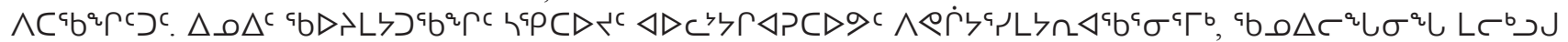

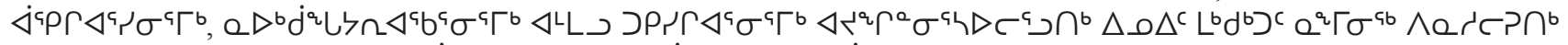

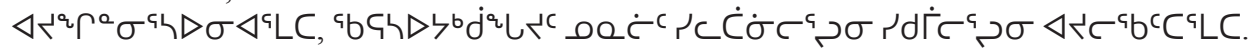

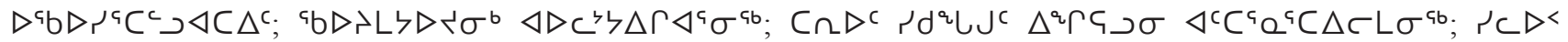

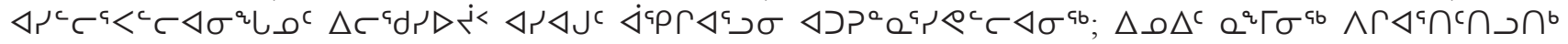
' $\mathrm{D} D \perp^{\mathrm{c}} \sigma \mathrm{\sigma b}$

Inuktitut Abstract and Acknowledgement tranlsations by Mishak Allurut, Ikpiarjuk, NU.

\section{INTRODUCTION}

Studies over the past 17 years have shown that climate change is resulting in increasingly dangerous sea ice travel conditions for Inuit (Fox, 2004; Tremblay et al., 2006; Laidler et al., 2010; Druckenmiller et al., 2013; Archer et al., 2017; Panikkar et al., 2018; Segal et al., 2020b). The reported high rates of sea ice travel-related search and rescue (SAR) requests and injury, trauma, and tragic deaths of Inuit are further evidence of dangerous sea ice travel conditions as a result of climate change (Durkalec et al., 2014; Clark et al., 2016a; Driscoll et al., 2016). Territorial, federal, academic, industry, and not-forprofit organizations have been developing climate change adaptation information to support safer sea ice travel for Inuit. Examples of additional information Inuit consult prior to travel include weather forecasts (ECCC, 2020a), satellite data (Polar View, 2019; Arctic Eider Society, 2020), and information from community-based weather and sea ice monitoring programs (SmartICE, 2020; Ittaq Heritage and Research Centre, 2021). When travelling on the sea ice, younger hunters are now relying more on global positioning systems (GPS) devices to navigate (Wenzel, 2004; Aporta and Higgs, 2005; Pearce et al., 2011; Christie et al., 2018).

What compounds the issue of safe sea ice travel for Inuit is the ongoing legacy of colonialism in the Canadian Arctic. Generations of Inuit were denied the experience of learning how to safely travel on the sea ice because as children they were either sent or taken away from their communities to attend residential schools (QIA, 2014). More recently, the shift to wage employment has led to an erosion of the Inuit Qaujimajatuqangit (IQ) skills necessary for sea ice travel and survival (Aporta and Higgs, 2005; Gearheard et al., 2006; Ford et al., 2007; Pearce et al., 2010, 2011, 2015; Heyes, 2011; Laidler et al., 2011; Durkalec et al., 2015). IQ is commonly used to describe Inuit knowledge, but it encompasses so much more than knowledge. IQ "embraces all aspects of traditional Inuit culture, including values, world-view, language, social organization, knowledge, life skills, perceptions and expectations" (Nunavut Department of Education, 2007:22). For a more in-depth description of IQ, see Kalluak (2017). In spite of these challenges, sea ice IQ endures and continues to be gained through experience and practice. Inuit who are out at their camps and cabins or who have recently returned to the community share their sea ice observations and knowledge, and these observations and experiences continue to be widely used by Inuit to make sea ice travel decisions (Ford et al., 2013a; ICC-Canada, 2014). Inuit have always experienced and adapted to variable sea ice and weather conditions from year to year; however, the nature and magnitude of recent changes are largely unprecedented in living memory (Pearce et al., 2010). Increased variability in weather and sea ice conditions due to climate change has left some experienced hunters doubting 
MOBILIZING INUIT KNOWLEDGE • 527

their weather and sea ice forecasting skills (Aporta, 2002; Gearheard et al., 2006, 2010; Ford et al., 2009; Laidler et al., 2011). However, many hunters still have confidence in their IQ to navigate and make critical decisions on the sea ice, even under changing sea ice conditions (Gearheard et al., 2006; Pearce et al., 2010). At a recent meeting with Inuit in Mittimatalik (Pond Inlet), Nunavut, one experienced sea ice traveller said, "When we're on the ice, all we have is our Inuit Qaujimajatuqangit" (Wilson, 2018a:4), as there is limited information to support Inuit once they leave their community and are on the sea ice. There have been some discussions about the need to improve the intergenerational transfer of sea ice IQ (Pulsifer et al., 2011; Pearce et al., 2015; Archer et al., 2017; Christie et al., 2018; Panikkar et al., 2018), but there are very few examples of mobilizing IQ as a sea ice safety adaptation strategy (Ford et al., 2007; Hackett et al., 2016; Aqqiumavvik, 2020; Ilisaqsivik, 2020).

This research paper provides a practical example of mobilizing IQ for safe sea ice travel to address the adaption needs of Inuit youth in the community of Mittimatalik. The goals of this paper are two-fold. First, we outline a coproduced, cross-cultural, Inuit-led research project that documented and mobilized sea ice IQ in Mittimatalik to support safe sea ice travel in the community. We present the methods used to train Inuit youth in facilitating the sea ice terminology and participatory mapping workshops to build capacity and to conduct this research themselves. We outline the geographic information systems (GIS) training and artistic methods used to mobilize the IQ that was most important to document. We also describe the unique ways this sea ice IQ was mobilized into a booklet, maps, and posters for different generations of Inuit with varying levels of Inuktitut proficiency and sea ice travel experience. Second, this paper demonstrates that sea ice IQ continues to be necessary and relevant for safe sea ice travel, even under changing sea ice conditions. The community-specific sea ice terminology in the booklet provides the foundation upon which Inuit youth can build their knowledge and experience. Mobilizing the Inuktitut sea ice terms equips youth with the ability to discuss and share sea ice conditions with more experienced Inuit hunters, which is especially critical during SAR events. While experienced hunters use novel information from weather forecasts, earth observations, and community-based monitoring sources to augment their knowledge, they are not reliant on them (Pulsifer et al., 2011; ICC-Canada, 2014; Pearce et al., 2015). IQ provides experienced Inuit sea ice users with the skills to interpret and synthesize these additional sources of information and apply them to their local conditions. The IQ maps provide Inuit youth with a baseline of seasonal knowledge for areas of safe and hazardous sea ice and areas for shelter. The sea ice terms and posters teach inexperienced hunters how to identify hazardous and safe sea ice conditions for safe navigation on the sea ice, filling spatial and temporal scales that additional information sources cannot address. The IQ products combined teach preparedness, situational awareness, and navigational skills so Inuit youth can become more self-reliant as technology is not always accessible or reliable out on the sea ice.

\section{BACKGROUND}

Inuit references to being out "on the land" include travel on land, water, and sea ice. In winter, the sea ice connects the land and provides greater access and mobility to areas that are separated by open water in the summer (ICC-Canada, 2008; Middleton et al., 2020). The sea ice becomes an extension of the land and so travelling "on the land" refers to travelling predominantly on the sea ice. Environmental changes to sea ice travel and travel on the land are having profound impacts on the physical, cultural, and mental health of Inuit. These impacts intersect with and amplify the effects of colonialism, which continue to interrupt the transfer of sea ice IQ to younger generations of Inuit.

\section{Climate Change Impacts on Sea Ice and Inuit}

Records show that sea ice in the Canadian Arctic has been decreasing at a rate of $7 \%$ per decade and all regions in the Canadian Arctic have experienced a decreasing trend in sea ice between 1968 and 2018 (ECCC, 2021). Climate change observations from various Inuit communities describe sea ice freezing later in the fall and breaking up earlier in the summer, and that there are changes to the quality and strength of sea ice and more areas of thin ice (Laidler et al., 2009, 2010; Cunsolo Willox et al., 2013; Ford et al., 2013b; Gearheard et al., 2013; Archer et al., 2017; Panikkar et al., 2018; Segal et al., 2020b). Similar observations have been documented for Mittimatalik (Manseau, 2006; Knight Piésold Consulting, 2015; Carter et al., 2018).

The high cost of store-bought foods in Inuit Nunangat (Inuit homelands in the Canadian Arctic) means that Inuit spend over three times the amount of an average Canadian on basic supplies, and Inuit food insecurity rates are eight times higher than the rest of Canada (Kenny et al., 2018a). Climate change is challenging Inuit communities that are reliant on the sea ice to provide access to necessary country food such as caribou, Arctic char, seal, and narwhal (Laidler et al., 2009; Clark et al., 2016a; Kenny et al., 2018b). Research shows that even modest amounts of country foods contribute critical sources of nutrition that cannot be replaced by store-bought proteins such as canned tuna, chicken, and beef (Kenny et al., 2018a, b; Anselmi, 2019). Country foods that comprise the traditional diet are significant aspects of Inuit cultural identity and taste preference. Although the amount of country food consumed by Inuit varies among communities, $80 \%$ of Inuit in communities in the western Canadian Arctic would prefer to eat more country food (Kenny et al., 2018a).

Climate change is also affecting Inuit physical and mental well-being. For Inuit, being on the land provides a 
sense of peace, wholeness, calm, healing, and enriches the soul (Cunsolo Willox et al., 2013; Middleton et al., 2020). Inuit have explained that travelling on the sea ice means freedom (Gearheard et al., 2013; Durkalec et al., 2015) and being unable to travel on the sea ice is directly connected to their mental and emotional health and well-being (Cunsolo Willox et al., 2013; Ford et al., 2013b; Durkalec et al., 2015; Pearce et al., 2015; Middleton et al., 2020). Rates of unintentional injury and trauma are extremely high in Inuit Nunangat (Durkalec et al., 2014); in Nunavut specifically, they "are more than twice the national average... and the leading cause of morbidity and mortality" (Clark et al., 2016a:1). In Alaskan Inuit communities, unintentional injury such as frostbite, hypothermia or drowning from falling through the ice was "significantly more likely in months when respondents reported unseasonable environmental conditions, and particularly so when they changed travel plans as a consequence of those conditions" (Driscoll et al., 2016:455).

SAR requests in Nunavut doubled between 2006 and 2015 (Clark et al., 2016b); of the approximately 300 SAR requests made each year, more than one-third occur in the transitional ice periods when the sea ice freezes up in the fall or as it breaks up in early summer (S. Baillie, pers. comm. 2017). The analysis of SAR records in Nunatsiavut and Nunavut found that requests have increased due to changing weather and sea ice conditions, but also due to mechanical breakdown and running out of gas (Durkalec et al., 2014; Clark et al., 2016a). Changing sea ice conditions mean that Inuit are no longer able to access traditional hunting and fishing areas and are now having to navigate new, longer, and more dangerous routes, which increase the risk of becoming lost in unfamiliar areas, using more fuel, and running out of gas. Breaking through unexpected areas of thin ice and having to travel over rough ice or land are resulting in snowmobiles and other equipment being lost and damaged (Ford et al., 2007; Durkalec et al., 2015; Driscoll et al., 2016; Fawcett et al., 2018). Despite the risks due to climate change of hunting and travelling on the sea ice, Inuit have argued that the benefits of sea ice travel for their physical, nutritional, cultural, spiritual, and mental health still outweigh the risks (Gearheard et al., 2011; Ford et al., 2013a; Durkalec et al., 2015; Clark et al., 2016b; Kenny et al., 2018b).

\section{Impacts of Colonialism on Inuit Sea Ice Travel Safety}

In the 1950s, Inuit were forced or induced to transition from land-based economies to settlement economies based on wage labour, as part of the Government of Canada's assimilation approach called the in-gathering policy (Tester and Kulchyski, 1994; Damas, 2002; Tester, 2017; MacDonald, 2018). Many Inuit children were either sent or taken away to residential schools, which resulted in generations of Inuit being deprived of the ability to develop their sea ice IQ through observations and experiences with their parents and Elders (ICC-Canada, 2014; QIA, 2014;
TRC, 2015). Colonialism has left many generations of Inuit unable to communicate in Inuktitut, which impacts their ability to learn, understand and share sea ice conditions and experiences with hunters and Elders (Heyes, 2011; Pearce et al., 2011; Ford et al., 2013a).

Settlement further contributed to the erosion of sea ice IQ with imposed work and school schedules that limit sea ice travel to weekends and holidays (Aporta and Higgs, 2005; Ford et al., 2007; Pearce et al., 2010, 2011, 2015; Heyes, 2011; Pulsifer et al., 2011; Durkalec et al., 2015; Panikkar et al., 2018). The introduction of the snowmobile in the 1960s allowed Inuit to travel greater distances in less time (Aporta, 2010; Ford et al., 2013b; Clark et al., 2016b; Panikkar et al., 2018). Weekend sea ice travel reduces the flexibility of Inuit to hunt when environmental conditions are at their best. This can lead to increased risky behaviour as people may leave the community in less-than-ideal weather conditions in order to return for school or work commitments (Gearheard et al., 2006; Meier et al., 2006; Ford et al., 2013a; Pearce et al., 2015; Clark et al., 2016b; Kenny et al., 2018a). The high rates of SAR are also related to wage employment. Inuit without a reasonable income cannot afford to purchase, fix, or replace the necessary equipment for safe travel on the sea ice (Heyes, 2011; Clark et al., 2016b). Snowmobiles are very expensive to purchase, fix and run. There are the costs of gas, extra gas, fuel for stoves, tents, clothing, food, VHF radios, GPS, and SPOT devices, and satellite phones. Snowmobiles with makeshift repairs can break down and leave Inuit stranded if they are unable to afford the necessary backup supplies (Clark et al., 2016b).

In summary, the high rates of unintentional injury and SAR of Inuit on the sea ice are not simply due to climate change but are intertwined with the ongoing effects of colonialism that have weakened the transmission of sea ice IQ through reduced language and practice (Tester and Kulchyski, 1994; Damas, 2002; MacDonald, 2018).

\section{Sea Ice Travel Adaptation Tools}

Better ice and weather information at community (local and regional) scales have been discussed to support Inuit climate change adaption needs for safer sea ice travel (Ford et al., 2007; Eicken et al., 2009; Eicken, 2013). Technological adaptation tools include access to weather, tide, and marine information, along with satellite imagery, GPS, and community-based sea ice monitoring (Table 1: columns 1 to 3). Community-based monitoring activities vary across the Arctic, but include the use of time-lapse photography, webcams, and coastal radar systems to monitor sea ice breakup, and equipment to measure local weather, sea ice, snow, and oceanographic conditions (Mahoney and Gearheard, 2008; Mahoney et al., 2009; Druckenmiller et al., 2010, 2013; Bell et al., 2014; Aqqiumavvik, 2020; Arctic Eider Society, 2020; Dufour-Beauséjour et al., 2020; Fox et al., 2020; Segal et al., 2020a; Ittaq Heritage and Research Centre, 2021). 


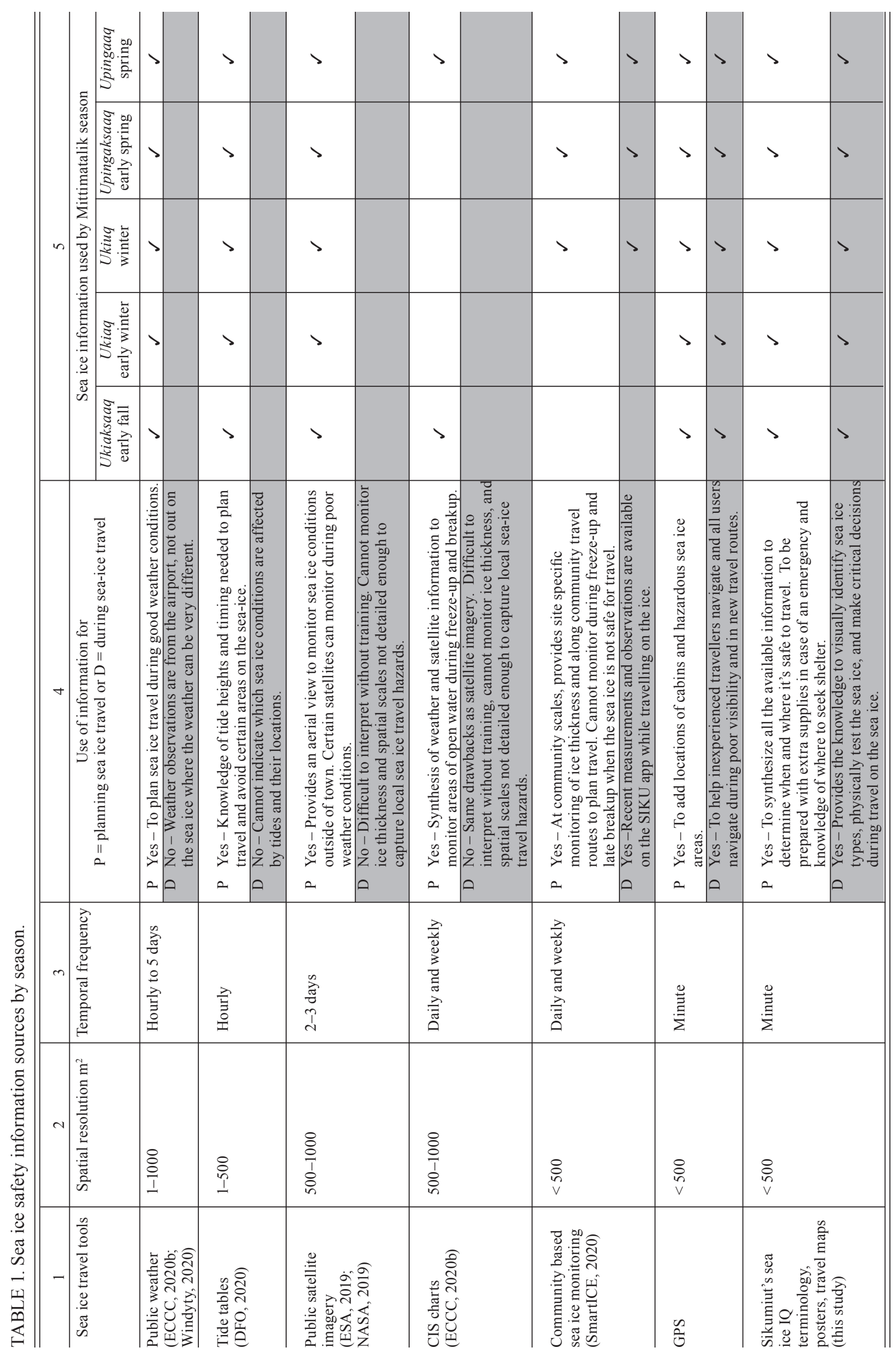


Satellite imagery and their derived products are another adaptation tool that Inuit are regularly consulting (Pearce et al., 2010, 2015; Laidler et al., 2011; Segal et al., 2020a) from websites such as SIKU (Arctic Eider Society, 2020) and Polar View (2019) (Table 1). Satellite imagery can benefit Inuit by providing an overhead view of the sea ice destinations farther from the community to help identify routes for safe sea ice travel (Meier et al., 2006; Laidler et al., 2011). Sea ice charts produced for Arctic shipping at the Canadian Ice Service (CIS) have been tested as another adaptation tool for Inuit (Table 1) (ECCC, 2020b). The ice charts are a set of daily or weekly maps that synthesize observational, satellite, and modelling data and describe the sea ice conditions using a numerical World Meteorological Organization (WMO) standard called "the egg code" (ECCC, 2016).

GPS devices are widely used by Inuit hunters to navigate while out on the sea ice (Table 1). The Igliniit project developed a mobile device for Inuit to monitor and track weather, wildlife, and sea ice observations (Gearheard et al., 2010, 2011). Hunters are able to mark the geographic location of dangerous sea ice conditions to share with the community. As most mobile phones now have locationtracking functionality, monitoring capabilities are now possible. The SIKU app was designed specifically for Inuit to map hazardous ice conditions. It is currently the only publicly available app that can share hazardous ice conditions broadly to other mobile devices and on the SIKU online social media platform (Arctic Eider Society, 2020).

Inuit Elders and experienced hunters highlight that all these technological tools can only augment Inuit knowledge; they do not replace the decision-making skills needed when travelling on the sea ice (Gearheard et al., 2006). Community-specific sea ice IQ provides the foundation for Inuit to adapt to climate change (Krupnik and Jolly, 2002; George et al., 2004; Tremblay et al., 2006; Ford et al., 2007; Pearce et al., 2015). To improve sea ice IQ, Inuit have recommended and implemented community safety workshops, hunter meeting places, and young hunter training programs (Ford et al., 2007; Hackett et al., 2016; Aqqiumavvik, 2020; Ilisaqsivik, 2020). The literature also has several examples of documenting and mapping Inuit sea ice IQ to preserve IQ (Heyes, 2011; Krupnik, 2011; Weyapuk and Krupnik, 2012), understand local sea ice processes (Laidler and Elee, 2008; Laidler and Ikummaq, 2008; Laidler et al., 2008; Heyes, 2011; Krupnik, 2011; Weyapuk and Krupnik, 2012), characterize conditions for wildlife migration (Ljubicic et al., 2018; Henri et al., 2020); undertake environmental assessments (Manseau, 2006; Knight Piésold Consulting, 2015), and develop Arctic shipping policy (Carter et al., 2018). However, there are only a few examples in which the documentation of sea ice IQ was done to improve safe sea ice travel (Tremblay et al., 2008; Arctic Eider Society, 2020; Fox et al., 2020; Nunavut Arctic College Media, 2020).

\section{METHODS}

Katherine Wilson, the lead author of this paper, is a $\mathrm{PhD}$ candidate with Memorial University of Newfoundland and an employee of the Government of Canada for over 25 years, with the CIS (17 years in total), Environment and Climate Change Canada, and currently on interchange with SmartICE. As a settler scholar and government employee, the lead author's multiple roles are both contradictory and complementary. The motivation for the lead author to return to school to retrain in decolonizing research approaches was to help create space in government and academia for reconceptualized approaches that better support Inuit selfdetermination in research (Wilson et al., 2020).

Coauthor Trevor Bell is the co-supervisor for Wilson and the founder of SmartICE. A work integration social enterprise, SmartICE (smartice.org) provides ice thickness measurements from in situ instruments (SmartBUOYs) located at strategic travel locations on the sea ice and a mobile sensor (SmartQAMUTIK) towed behind a snowmobile throughout the season on the main sea ice trails (Bell et al., 2014). Bell and Wilson have been working in Mittimatalik since 2015.

\section{Community Context}

The population of Mittimatalik is approximately 1600 , with $92 \%$ identifying as Inuit and with Inuktitut as their mother tongue (Statistics Canada, 2017). The community of Mittimatalik is located at the northern tip of Baffin Island in the Qikiqtaaluk region of Nunavut (Fig. 1). Sirmilik (Bylot Island), which means "place of glaciers," lies across Tursukattak (Pond Inlet) from the community (Fig. 1). The sea ice is the primary transportation platform for hunting, fishing, and travel to family cabins, and the sea ice travel season for Mittimatalik is approximately eight months long (ICC-Canada, 2008, 2014). The ocean water around the community typically begins to freeze in late October and is safe enough for travel in late November once the ice becomes tuvaq (land-fast ice or stable sea ice that is frozen to the land). A boundary sea ice feature called sinaa (floe edge) starts to establish in November between the stable tuvaq in Tursukattak and the southward-moving mobile sea ice in Saknirutiak Imanaga (Baffin Bay) (Fig. 1). Dominant westerly weather patterns push the Saknirutiak Imanaga sea ice farther away from the sinaa, providing a naturally occurring area of open water. Located approximately 65 $\mathrm{km}$ from the community, the Tursukattak sinaa is one of the main hunting and fishing locations, as it provides a stable platform to access marine-based country food (narwhal, beluga, seal, and char) for Mittimatalingmiut (people of Mittimatalik). Mittimatalingmiut hunters will commonly tow small aluminum boats on a qamutik (Inuit sled) behind their snowmobiles to hunt and fish in the open water at the sinaa. Mittimatalingmiut will hunt and fish on the sea ice until late June or early July when the sea ice starts to break up. 


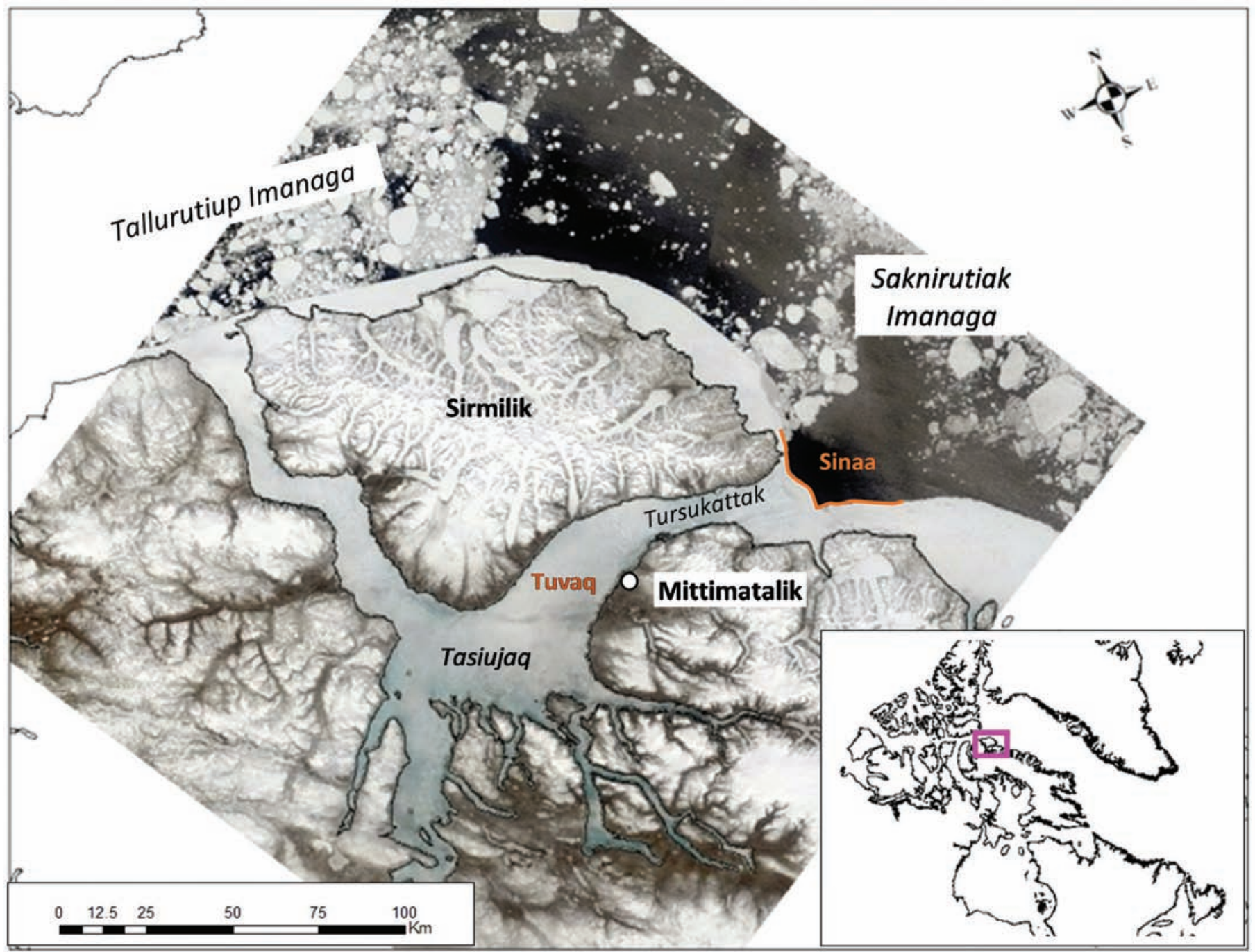

FIG. 1. Location of the community of Mittimatalik, Nunavut, Canada. Background image MODIS True Color Composite, 9 June 2019 (NASA, 2019).

\section{Codeveloping the Research Approach}

Bell and Wilson spent the first two years developing relationships and trust in order to set up the SmartICE community-based sea ice monitoring service. Coauthor Andrew Arreak was hired in 2015 and trained as the SmartICE Community Operator for Mittimatalik and the Nunavut Operations Lead for Qikiqtaaluk North.

In 2016, a 10-person committee of Elders, as well as experienced and emerging sea ice users, was established to govern SmartICE in Mittimatalik. Sikumiut, which means "people of the sea ice" in Inuktitut, is the self-titled name of the management committee (SmartICE, 2020). In September 2017, the members of Sikumiut (also coauthors on this paper) were at a point they felt comfortable enough to discuss their research needs with Bell and Wilson. Sikumiut expressed that they were very pleased with initial SmartICE operations, but younger generations lacked the fundamental IQ to keep them safe while they are traveling on the sea ice. Sikumiut identified the need to document and mobilize their IQ to support safe community sea ice travel. While southern researchers have recorded and mapped sea ice IQ in Mittimatalik, it was always done for external purposes such as the establishment of Sirmilik National Park (Manseau, 2006), environmental assessments for the Mary River mine (Knight Piésold Consulting, 2015), and consultations for the Canadian Coast Guard's Arctic shipping corridors (Carter et al., 2018). Because previous sea ice IQ was not collected with the intent for use by Mittimatalingmiut, the result was a collection of IQ that could not be repurposed for Sikumiut needs.

During 2017, Bell and Wilson sought funding to address Sikumiut's research needs. It was also during the third year that time was spent codeveloping the Sikumiut Model (Wilson et al., 2020), which is a cross-cultural research approach based on the following six goals: 1) support Inuit self-determination in research, 2) embrace Inuit decision making, 3) prioritize community-based research needs, 4) develop Inuit specific values for research; 5) strengthen Inuit youth capacity, and 6) change the role of nonIndigenous research partners. 
In the Sikumiut model, the research is focused on community-identified research needs. Sikumiut provided the direction on what sea ice IQ they felt was most important to document and how it would be most appropriate to share and mobilize their knowledge. Strong emphasis was placed on building Inuit youth capacity in research and on enhancing the intergenerational transfer of sea ice IQ. Therefore, the role of the non-Indigenous research partners was reconceptualized as facilitators and mentors for Inuit youth in Mittimatalik to do this research themselves. Arreak was the Inuit youth researcher for the Sikumiut project outside of the SmartICE monitoring season. Youth Sikumiut members were encouraged to participate fully in all the meetings and workshops to expand their sea ice IQ as emerging knowledge holders. A research agreement between Sikumiut and Memorial University was developed to outline the project plan, as well as the roles and responsibilities of Inuit and non-Inuit project partners (Wilson, 2018b). The research agreement also outlined that the data from this project were owned by Sikumiut, and consent was given to Wilson to publish the results as part of her $\mathrm{PhD}$ requirements.

Sikumiut were interested in new ways to document and communicate their IQ to share with the community to improve safe sea ice travel. As one Elder Sikumiut member stated, "In the past we never had writing tools, so we did not record these things. This will be the first time we have documented our sea ice knowledge" (Wilson, 2018a:4). In reviewing possible methods to map their IQ, Sikumiut emphasized the importance of starting with documenting Inuktitut sea ice terminology. In an oral culture, the Inuktitut terms are key to identify and communicate sea ice conditions and hazards. Documenting and sharing Inuktitut sea ice terminology were considered the foundation upon which Sikumiut could build to more effectively mobilize their IQ. All of the workshops and validation meetings were held in Inuktitut to enable conversations and ideas to flow freely without interruption. Simultaneous translation into English was provided mostly for the non-Indigenous research partners and to assist youth members who are not fully bilingual.

\section{Sea Ice Terminology Workshops}

The initial workshops to document local Inuktitut sea ice terminology occurred over three days in October 2018. Elder Sikumiut members requested the participation of two other community Elders with significant sea-ice IQ. In total six Elders shared their IQ with three younger Sikumiut members listening. The terminology workshop used methods based on research in Kinngait, Igloolik, and Pangnirtung (Laidler and Elee, 2008; Laidler and Ikummaq, 2008; Laidler et al., 2008). Coauthor Gita Ljubicic is also a co-supervisor for Wilson. Ljubicic was present to help mentor and train Arreak and Wilson in the methods and cofacilitation of the workshops. The first day was a review of the Mittimatalik freeze-up and winter sea ice conditions, and the second day focused on sea ice breakup. The third day was used for initial validations and refinement of the terms and definitions, as well as to clarify any questions. As each Inuktitut sea ice term was discussed, the term was written in bold, large letters on a 4 -inch by 6 -inch index card, with the definition below it. The word and definition were discussed for translation into English and written on the other side of the card. For many of the sea ice terms, there were no equivalent English terms, so these terms were rewritten in Inuktitut, with English definitions. This method of having the Inuktitut and English on one card ensured that the translations did not get mixed up. It also allowed for Sikumiut to collectively agree on the spelling and definitions of the terms. Arreak wrote the Inuktitut words and definitions on the card and Ljubicic wrote the English words and definitions. Wilson took notes of the overall discussion amongst the Sikumiut members, such as the questions and clarifications asked, and the associated examples or stories that Sikumiut members provided. The index cards enabled a hands-on experience during the workshop. The cards were placed on the table and Sikumiut members could point to the card, pick it up, edit it themselves, and arrange the cards based on the discussion (e.g., to explain the various stages of sea ice freeze-up). The cards were also taped to the wall and arranged in a seasonal progression for review and adjustment (Fig. 2). Sikumiut then suggested the production of a small booklet of sea ice terminology, with accompanying photographs and illustrations of ice conditions, to be distributed to households as an important learning tool.

\section{Sea Ice Mapping Workshops}

In November of 2018 a one-day workshop was held to map Sikumiut's seasonal sea ice knowledge of safe and hazardous areas. Four Elder and two youth Sikumiut members were present. The participatory mapping methods used were based on a previous research partnership in the community, in which Arreak had already received training (Carter et al., 2019; Dawson et al., 2020). We started by discussing the different sea ice seasons, and Sikumiut agreed on two distinct seasons that were most important to map: November to April, once the sea ice is frozen and stable, and May to July, when the sea ice is breaking up. We used paper copies of the Canadian Hydrographic Service Nautical Chart \#7212 for the Mittimatalik region as the base map because it provided the greatest oceanographic and topographic details for the area. Sikumiut members were encouraged to draw features directly on the maps in pencil. Once consensus was reached on the feature, Arreak then used markers to trace and number the features on the map, as Wilson recorded the feature descriptions in detail. Following the mapping workshops, Lynn Moorman (Mount Royal University) and Wilson trained Arreak on the GIS software ArcMap (version 10.5). Digital pictures of the paper maps were imported into ArcMap and georeferenced. Arreak was then able to digitize the sea ice features drawn 


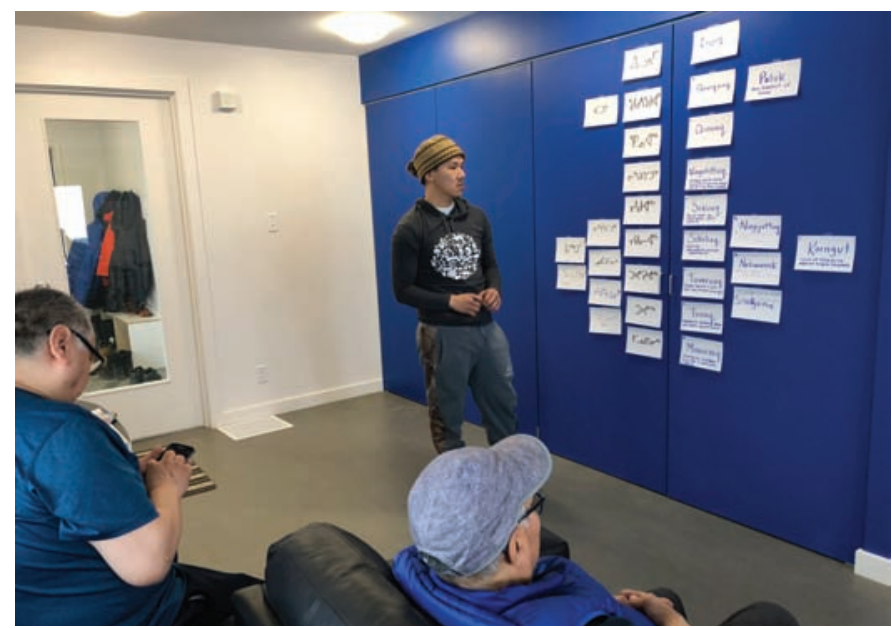

FIG. 2. Arreak facilitating the Sea Ice Terminology Workshops with Sikumiut members in Mittimatalik, Nunavut, on 14 October 2018. Photo Credit Katherine Wilson.

by Sikumiut by tracing the features on the georeferenced map photo to create the digital maps.

\section{Sea Ice IQ Posters}

In debriefing with Sikumiut after the terminology and mapping workshops, it became apparent that not all of the IQ shared could be defined as a term or captured on a map. This outstanding knowledge detailed such things as how to prepare for sea ice travel and how to identify and navigate hazardous sea ice conditions while on the sea ice. Coauthor Jamesie Itulu is a young Mittimatalik artist recommended by Sikumiut youth members to develop graphical illustrations for the posters. Itulu joined the research team in 2018 to specifically address and mobilize this IQ through art. Itulu continued with the research team to also develop graphical illustrations to support the sea ice terminology booklet.

\section{Sea Ice IQ Validation Meetings}

Arreak facilitated a total of 14 validation meetings with Sikumiut between January 2019 and November 2020 to confirm and revise the documented sea ice IQ, and to discuss the methods to mobilize this knowledge through a booklet, maps, and posters. Meetings between October 2018 and February 2020 were scheduled when Wilson, Bell, Ljubicic, and Moorman came to the community. After March 2020, the COVID-19 pandemic restricted research travel for the non-Inuit research partners living outside of Nunavut; however, the pandemic did not interrupt the project. Arreak continued to independently organize and facilitate in-person Sikumiut meetings in Mittimatalik, with the non-Inuit partners participating by telephone. With well-established relationships, local research capacity, and leadership, we were able to continue our work together despite the pandemic.

Over two years, the experienced Sikumiut hunters methodically reviewed the terms, illustrations, maps, and posters to confirm the accuracy of Inuktitut spellings, descriptions of ice conditions, mapping of important hazards, and poster and booklet illustrations. Elder members requested different generations of Mittimatalingmiut on the Sikumiut committee so that this sea ice knowledge could be passed on. Being part of the process of documenting Sikumiut's IQ and creating the products provided an important learning opportunity for youth members to expand their sea ice IQ and language skills. Sikumiut youth members reviewed the products to ensure that they were accessible to different generations of Inuit with varying levels of sea ice experience and language proficiency. For example, in Mittimatalik, Inuktitut Roman orthography is preferred by the younger generation, Inuktitut syllabics are preferred by the older generation, and having English was also considered important to reach a broader audience of youth that is not as comfortable in Inuktitut. As a result, all the products were designed to include two Inuktitut fonts and English. Having youth involved from the outset was an important aspect so they could learn through the process, but also provide guidance on how to best reach Inuit of their own generation.

Sikumiut members provided direction on the methods used to document and mobilize their IQ. What started off as a list of Inuktitut terms has now evolved into a booklet. While Sikumiut would like to see this information available on the SmartICE website, it was also important to them that this information be made accessible to everyone. The decision was made to create a small paper booklet that could be duplicated in affordable ways so that every household in Mittimatalik could receive a copy. While mobilizing Sikumiut IQ through maps, posters, and a booklet utilizes more modern communications tools, what was unique about this approach was that Inuit adapted these tools, using Inuktitut language, knowledge, and artwork.

\section{RESULTS}

The Sikumiut sea ice IQ products complement one another and provide an example of what IQ could be documented and what was important to document to improve sea ice travel safety from an Inuit perspective. The contents of the Sikumiut sea ice IQ products are best described by their application throughout the different seasons in Mittimatalik (Fig. 3). Of the six typical seasons in Mittimatalik, sea ice is present in five: ukiaksaaq (early fall, late September), ukiaq (late fall, October-November), ukiuq (winter, December-February), upingaksaaq (early spring, March-May), and upingaaq (spring, June-July). Aujaq (summer, August-early September) will not be discussed as sea ice is normally not present at this time of year.

The workshops and meetings to document, validate, and mobilize Sikumiut's sea ice IQ have resulted in a Mittimatalik sea ice IQ booklet containing 67 sea ice terms with accompanying photos or illustrations (see Figs. 4-8 for excerpts from the sea ice terminology booklet), 


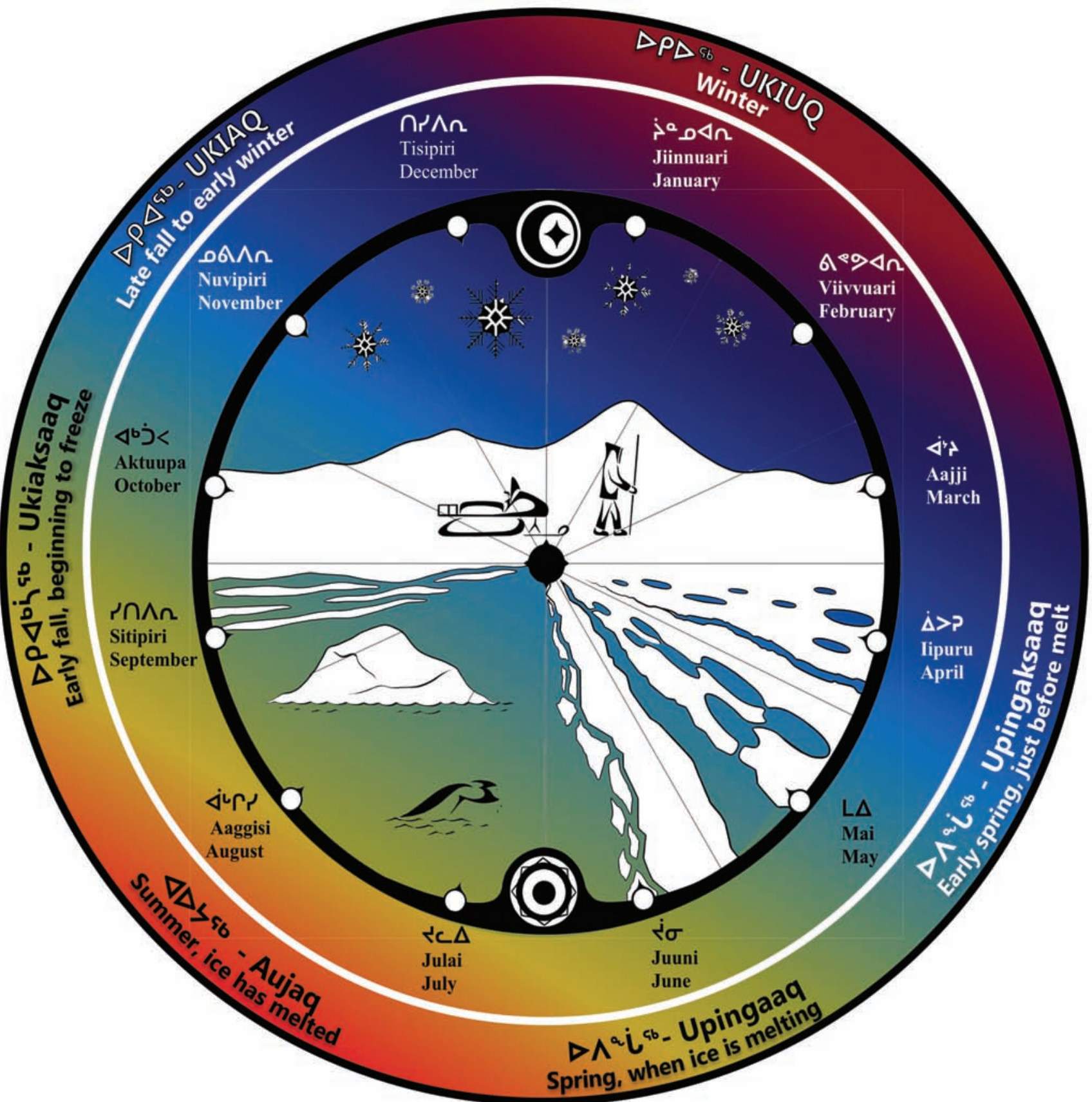

FIG. 3. The Mittimatalik seasonal sea ice cycle. Illustration by Jamesie Itulu.

three Sikumiut seasonal sea ice IQ travel maps (Figs. 9-11), and two Sikumiut sea ice IQ travel safety posters (Figs. 12 and 13).

\section{Ukiaksaaq (Late Summer/Early Fall)}

Between late September and the end of October, the amount of daylight has reduced from approximately 12 to 5 hours (Timeanddate.com, 2020), the daily average October air temperature is $-9.7^{\circ} \mathrm{C}(\mathrm{ECCC}, 2020 \mathrm{~b})$, and the initial signs of winter are starting in Mittimatalik. This season is known as ukiaksaaq (Fig. 3), when the sea ice is beginning to freeze up and Mittimatalingmiut know that their ability to hunt and fish by motorboat is about to end. Travel on the sea ice is not yet possible and the sea ice terms, definitions, and photographs or illustrations are intended to help Mittimatalingmiut to visually identify new ice types to safely navigate through with their motorboats, and determine when navigation through the sea ice is no longer possible (Fig. 4). Quvviqquaq is a very thin layer of sea ice that a motorboat can still navigate through. Qinuaq is a thicker layer of sea ice slush that you cannot drive through or it will damage the boat motor. You can still break, paddle, and push your boat out of qinuaq along the shore to get out to the open water. Ningutittuq is the final, dense stage of slush. It is an indicator that the sea ice is about to 


\begin{tabular}{|c|c|c|c|}
\hline \multicolumn{4}{|c|}{ 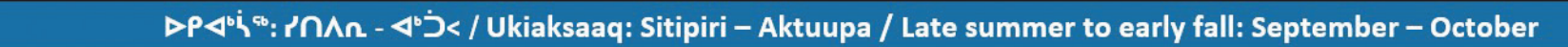 } \\
\hline \# & Term & Definition & Photograph or Illustration \\
\hline \multirow{3}{*}{1} & 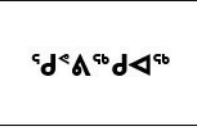 & 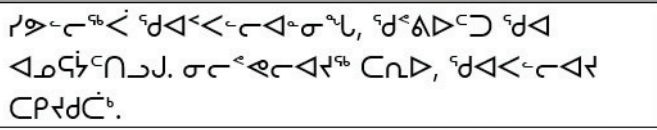 & \\
\hline & \multirow{2}{*}{ Quvviqquaq } & $\begin{array}{l}\text { Sivulliqpaa quappallianninga, quvviuttu qua } \\
\text { anurajaattilugu. Nilivvaliajuq tariu, quapalliaju } \\
\text { takijukutaak. }\end{array}$ & \\
\hline & & $\begin{array}{l}\text { First stage of freeze up. When ice is forming, and } \\
\text { the wind is stretching out the ice and elongating it. } \\
\text { It looks like frozen tears. }\end{array}$ & \\
\hline \multirow{3}{*}{2} & ${ }^{c} P \mathrm{~S}^{\mathrm{cb}}$ & 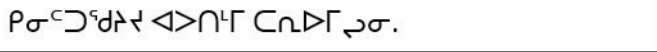 & \\
\hline & \multirow[b]{2}{*}{ Qinuaq } & Kinittuqujiju aputimmi tariumi\&uni & \\
\hline & & $\begin{array}{l}\text { Slushy ice, no strength to it (cannot hold a person's } \\
\text { weight), but difficult to paddle through. }\end{array}$ & \\
\hline \multirow[b]{3}{*}{3} & $\sigma^{a} J^{\mathrm{cb}} \cap כ^{\mathrm{cb}}$ & 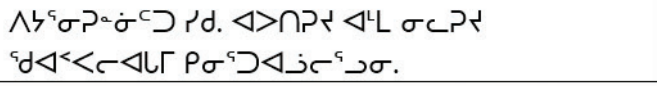 & \\
\hline & & $\begin{array}{l}\text { Pijarnirunniittu siku. Aputiruju amma nilaruju } \\
\text { quappaliagami kinirtualuulirluni. }\end{array}$ & \\
\hline & Ningutittuq & $\begin{array}{l}\text { Denser than qinuaq but still slush. Snow can } \\
\text { accumulate on top, but it is not yet solid ice. You } \\
\text { cannot use your paddle, starting to get hard to } \\
\text { travel by boat. Used to predict when other areas } \\
\text { will freeze. }\end{array}$ & $\begin{array}{c}\text { Ningutittuq (3). } \\
\text { Photo credit Katherine Wilson. } \\
\text { Quvviqquaq (1) and Qinuaq (2) not shown. }\end{array}$ \\
\hline
\end{tabular}

FIG. 4. Sikumiut terms for sea ice during ukiaksaaq (late summer to early fall: September-October) excerpted from the Sikumiut sea ice IQ booklet.

\begin{tabular}{|c|c|c|c|}
\hline \# & Term & Definition & Photograph or Illustration \\
\hline \multirow{3}{*}{4} & rdবsb & 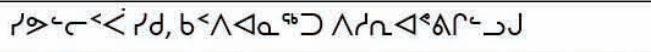 & \\
\hline & \multirow[b]{2}{*}{ Sikuaq } & Sivullippaa siku, kappianaqtu pisuriavvigillugu & \\
\hline & & $\begin{array}{l}\text { First thin layer of ice, still very thin, can see seals } \\
\text { popping up. Sea water rising. }\end{array}$ & \\
\hline \multirow[b]{3}{*}{5} & rde $4^{a b}$ & MreAhDrrd مC் & \\
\hline & & Pisuvvisauju siku nutaaq & \\
\hline & Sikuliaq & $\begin{array}{l}\text { Thicker than Sikuaq. If the harpoon goes through } \\
\text { the ice after one strike it is too thin and dangerous } \\
\text { to walk on. If it holds two strikes in the same hole, } \\
\text { it is safe to walk on. }\end{array}$ & \\
\hline \multirow{3}{*}{6} & $\sigma^{a}>\zeta^{c} \supset^{a b}$ & 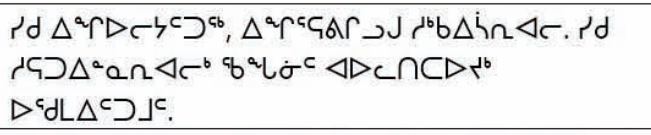 & \\
\hline & & $\begin{array}{l}\text { Siku ingiulijattuq, ingirravigilugu sukkaisaariali } \\
\text { uqumaittumut. }\end{array}$ & \multirow{2}{*}{$\begin{array}{c}\text { Ningijattuq (6). } \\
\text { Illustration: Itulu, } 2020 \\
\text { Sikuaq (4) and Sikuliaq (5) not shown. }\end{array}$} \\
\hline & Ningijattuq & $\begin{array}{l}\text { Flexible ice that moves as you travel on } \\
\text { snowmobile. Need to check with harpoon. Slow } \\
\text { travel only by snowmobile as the weight of the } \\
\text { snowmobile can create waves underneath the ice } \\
\text { and cause it to crack. }\end{array}$ & \\
\hline
\end{tabular}

FIG. 5. Sikumiut terms for sea ice during $u$ kiaq (late fall to early winter: October-November) excerpted from the Sikumiut sea ice IQ booklet.

become solid and community members need to pull their motorboats from the ocean before they get frozen in (Fig. 4). There were no maps or posters created for this season, since Mittimatalingmiut are not yet travelling on the sea ice. However, during a recent meeting in November 2020, Sikumiut suggested developing a poster to provide advice on safely navigating a motorboat during the early stages of sea ice freeze-up. 


\begin{tabular}{|c|c|c|c|}
\hline \# & Term & Definition & Photograph or Illustration with Term \# \\
\hline \multirow[b]{3}{*}{7} & Q'Jn & 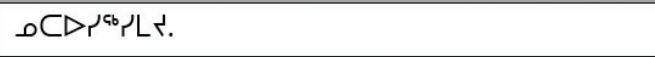 & \\
\hline & \multirow{2}{*}{$\begin{array}{l}\text { Nagguti } \\
\text { (singular) } \\
\text { Naggutiit } \\
\text { (plural) }\end{array}$} & Nutausiqsimaju. & \\
\hline & & $\begin{array}{l}\text { A crack in the sea ice. Once it cracks it reoccurs in } \\
\text { the same spot or near the same spot throughout } \\
\text { the whole winter }\end{array}$ & \\
\hline \multirow{3}{*}{8} & a'Jpcכab & 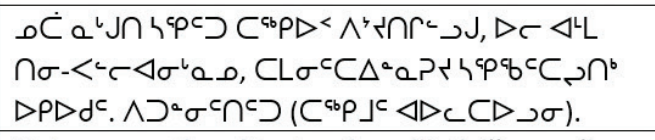 & \\
\hline & \multirow[t]{2}{*}{ Naggusittuq } & $\begin{array}{l}\text { Nutaa nagguti saqittu taqqiup pijjutigillugu, uli } \\
\text { amma tini-pallianignanu, tamanittainnaruju } \\
\text { saqiqatta\&utik ukiukut. Pitunnittittu (taqqimut } \\
\text { aulatauluni). }\end{array}$ & \\
\hline & & $\begin{array}{l}\text { The cracking or re-cracking of the sea ice due to } \\
\text { high tides during a new or full moon. }\end{array}$ & \\
\hline \multirow[b]{3}{*}{9} & 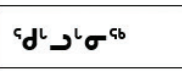 & 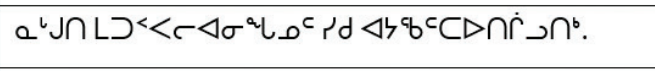 & \\
\hline & \multirow[b]{2}{*}{ Quglugniq } & $\begin{array}{l}\text { Nagguti matuppalianinganut siku } \\
\text { ajaqattautigiilutik. }\end{array}$ & \\
\hline & & $\begin{array}{l}\text { The closing of nagguti. The sea ice pushes against } \\
\text { each other and creates a pile or ridge along where } \\
\text { the nagguti was. }\end{array}$ & $\begin{array}{l}\text { Nagguit (7). Source: Ljubicic, } 2004 \\
\text { Naggusittuq (8) and Quglugniq (9) not shown }\end{array}$ \\
\hline
\end{tabular}

FIG. 6. Sikumiut terms for sea ice during ukiuq (winter: December-February) excerpted from the Sikumiut sea ice IQ booklet.

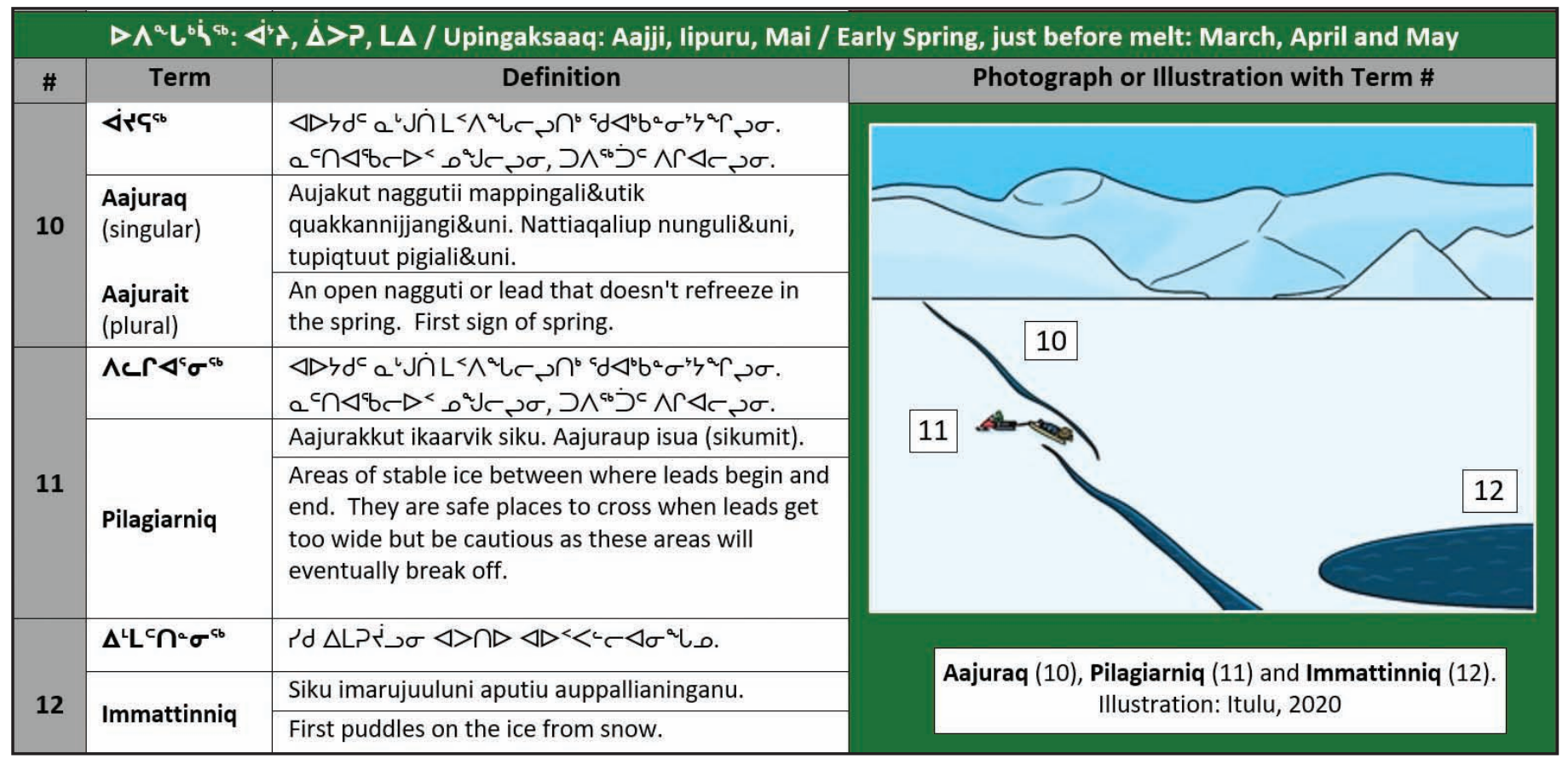

FIG. 7. Sikumiut terms for sea ice during upingaksaaq (early spring, just before melt: March-May) excerpted from the Sikumiut sea ice IQ booklet.

\section{Ukiaq (Late Fall/Early Winter)}

During ukiaq, from late October until the end of November (Fig. 3), the available daylight continues to decline. By mid-November there are zero hours of daylight (Timeanddate.com, 2020) with a daily average air temperature of $-21.7^{\circ} \mathrm{C}$ (ECCC, 2020b). Mittimatalingmiut can no longer hunt and fish by motorboat and are waiting for the sea ice to become thick enough to travel safely by snowmobile. This transition period can be a frustrating time as Mittimatalingmiut wait for the sea ice to freeze up so they can get back out on the land. As the ice is freezing and thickening, it is a difficult and dangerous time to know when the sea ice is safe to travel on. The Sikumiut sea ice 


\begin{tabular}{|c|c|c|c|}
\hline \multicolumn{4}{|c|}{ 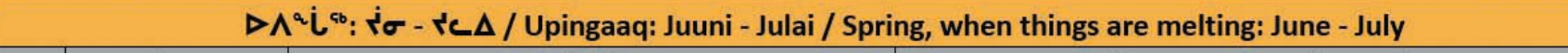 } \\
\hline$\#$ & Term & Definition & Photograph or Illustration \\
\hline \multirow[b]{3}{*}{13} & 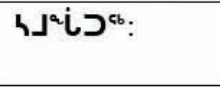 & 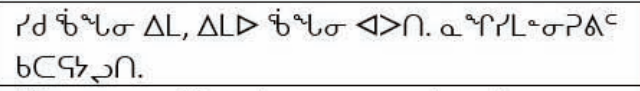 & \multirow[b]{3}{*}{$\longrightarrow$} \\
\hline & & $\begin{array}{l}\text { Siku qaangani ima, imau qaangani aputi. } \\
\text { nangisimanniruvit kataraja\&uti. }\end{array}$ & \\
\hline & Samunngaatuq & $\begin{array}{l}\text { The surface has a little bit of snow/slush covering } \\
\text { ice underneath. Difficult to travel and easy to get } \\
\text { stuck. When standing your feet will go through } \\
\text { to the ice, but you won't fall through to the open } \\
\text { water. }\end{array}$ & \\
\hline \multirow[b]{3}{*}{14} & PĆrb & 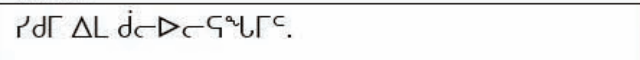 & \\
\hline & \multirow[b]{2}{*}{ Kilaajuk } & Sikumi ima kuuliulirangamit & \\
\hline & & $\begin{array}{l}\text { When the meltwater begins to drain through the } \\
\text { ice making many drainage channels or holes. } \\
\text { This signals that the sea ice travel season is } \\
\text { ending soon. }\end{array}$ & \\
\hline \multirow[b]{3}{*}{15} & hـ & 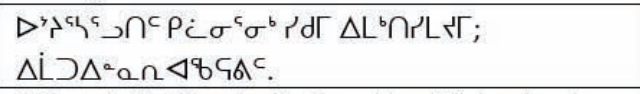 & \\
\hline & & $\begin{array}{l}\text { Ujjirsarlutit kilaanirnik sikumi imaktisimajumi; } \\
\text { imaatuinnariaqaravit. }\end{array}$ & \multirow[b]{2}{*}{$\begin{array}{l}\text { Kilaajuk (14), Illustration: Itulu, } 2020 . \\
\text { Samunngaatuq (13) and Saluraq (15) not shown. }\end{array}$} \\
\hline & Saluraq & $\begin{array}{l}\text { When the melting water on the sea ice surface } \\
\text { has drained. The sea ice surface has dried up and } \\
\text { the ice is full of drainage channels (Killak). The } \\
\text { ice is rotten and getting thinner fast as it } \\
\text { continues to melt rapidly. }\end{array}$ & \\
\hline
\end{tabular}

FIG. 8. Sikumiut terms for sea ice during upingaaq (spring, when things are melting: June-July) excerpted from the Sikumiut sea ice IQ booklet.

terminology describes the visual indicators and how to test the new sea ice types during ukiaq (Fig. 5). For example, sikuaq is the first thin solid layer of sea ice. You can see seals popping up in the sikuaq, but it is not yet strong enough for the seals to rest on the ice (Fig. 5). The terms describe how to test the sea ice for safety with a harpoon. If you strike the sea ice hard with your harpoon and it goes through with one strike, it is still sikuaq and is too thin and dangerous to walk on. If the sea ice holds after two harpoon strikes in the same spot, it is safe to walk on and this is called sikuliaq (Fig. 5). When the sea ice holds after three harpoon strikes in the same spot, it is now possible to travel on; however, the sea ice is still flexible at this time of year. The terms also describe how to carefully and slowly drive your snowmobile on ningijattuq, so the sea ice does not break as you drive (Fig. 5).

The Sikumiut map for November to July (Fig. 9) shows the traditionally safe snowmobile routes in green, which are mainly established by experienced hunters at the beginning of ukiaq. These trails were mapped by Sikumiut so that Mittimatalingmiut with less sea ice experience could learn about them and follow these routes. Figure 9 also highlights the locations of cabins and places to take shelter from high winds or poor weather conditions, with supporting latitude and longitude coordinates for input into personal GPS devices. As most young hunters travel with GPS devices, having the coordinates on the maps was important to Sikumiut. Inuit cabins are typically left equipped with supplies to provide for emergency shelter and survival for any travellers who find themselves stuck in bad weather or with machinery failure. Figure 12 ("Are you prepared to travel on the ice?") outlines the preparations and supplies needed in advance of travelling throughout all the sea ice seasons. The recommendation to never travel alone was not just because "two heads are better than one" but based on the understanding that not everyone can afford to purchase supplies. Therefore, travelling with more than one person also improves the chances that there will be an adequate combination of emergency supplies. Figure 13 ("What to know as you travel on the sea ice") explains with illustrations how to test the sea ice with your harpoon and the number of strikes required to determine if it is safe to walk on or drive on with a snowmobile.

\section{Ukiuq (Winter)}

The winter season in Mittimatalik covers the months of December, January, and February (Fig. 3). Temperatures reach their coldest in February, with daily averages of $-33.8^{\circ} \mathrm{C}$ (ECCC, 2020b), and Inuit hunters have been travelling with zero sunlight for roughly 3 months between mid-November and the end of January (Timeanddate. com, 2020). Sikumiut's sea ice terminology explains the process of naggusittuq, how the sea ice will crack (nagguti) 


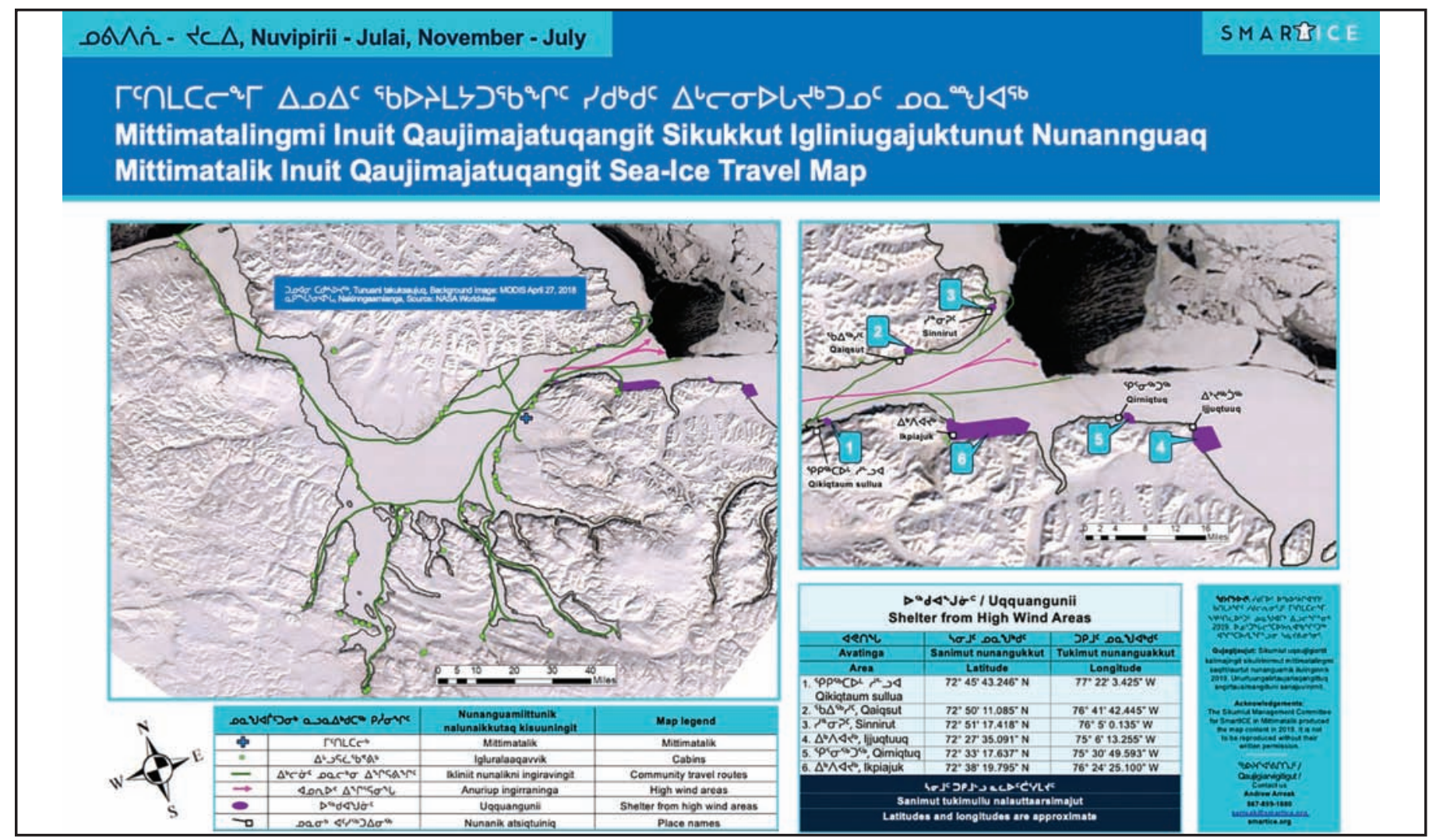

FIG. 9. Safe travel routes and areas for shelter for the entire Mittimatalik sea ice travel season: November to July. To view in more detail please go to https://smartice.org/ice-safety/.

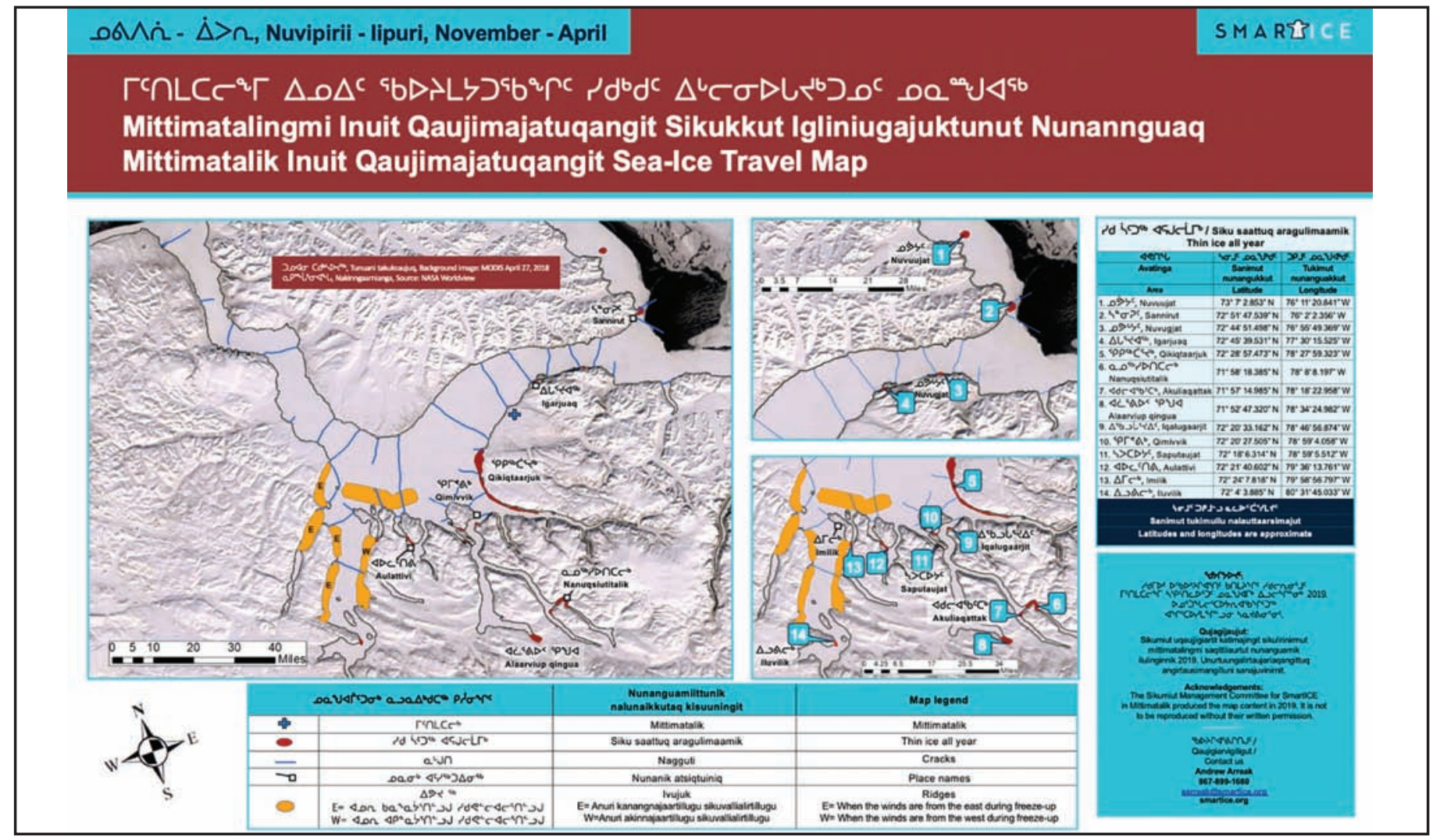

FIG. 10. Areas of known sea ice travel hazards for the late fall to early spring travel season: November to April.n To view in more detail please go to https://smartice.org/ice-safety/. 


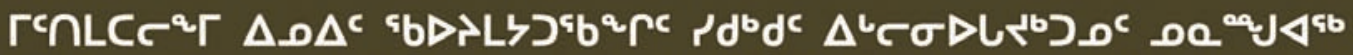 Mittimatalingmi Inuit Qaujimajatuqangit Sikukkut Igliniugajuktunut Nunannguaq Mittimatalik Inuit Qaujimajatuqangit Sea-Ice Travel Map}
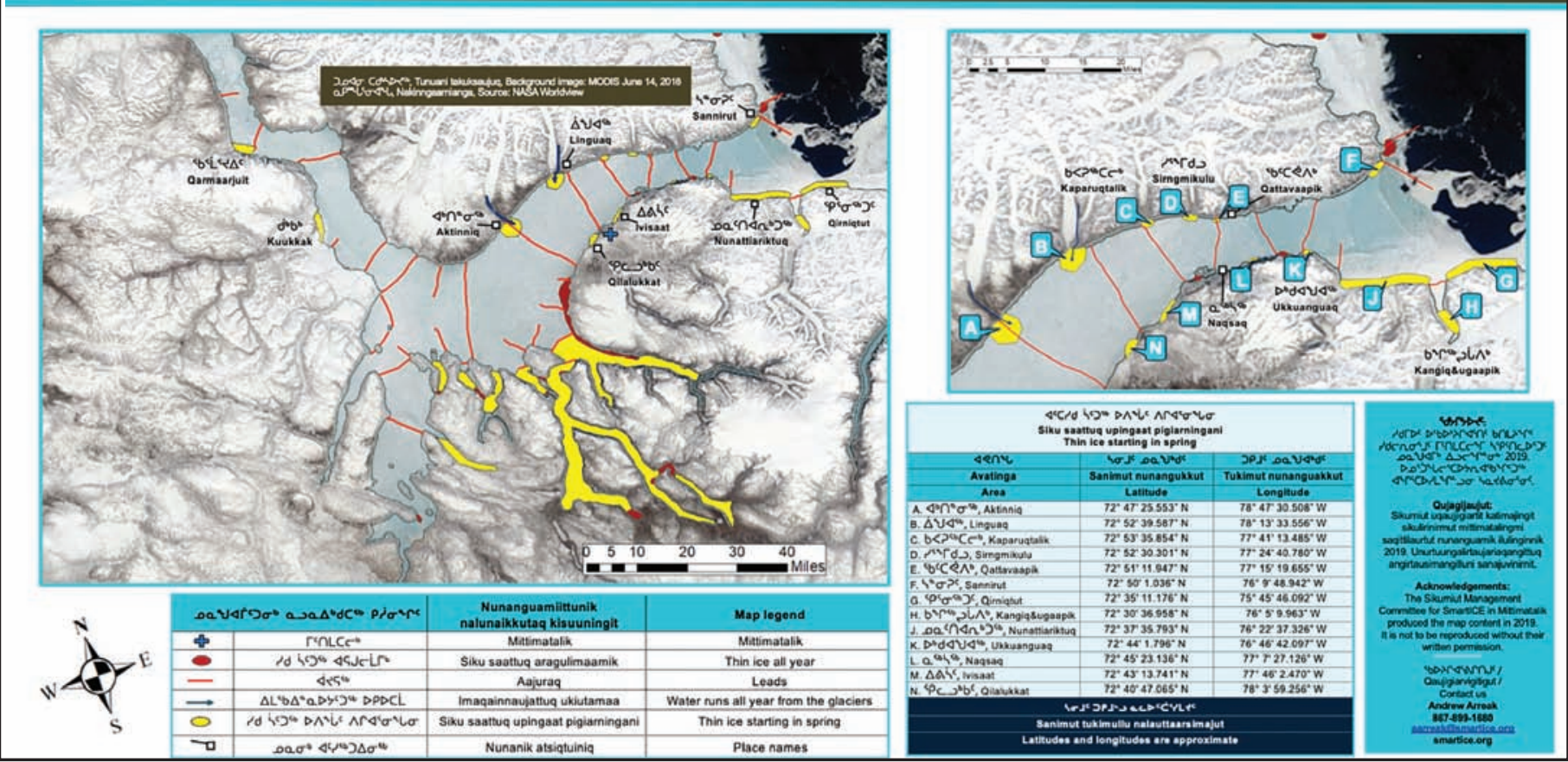

FIG. 11. Areas of known sea ice travel hazards for spring breakup travel season: May to July. To view in more detail please go to https://smartice.org/ice-safety/.

because of high tides during a new or full moon, refreeze (quglugniq) and re-crack (Fig. 6). Once a crack in the sea ice occurs, it will freeze and re-crack in the same spot throughout the winter (Fig. 6).

In the extreme cold conditions of ukiuq, snowmobiles and equipment are more likely to break down. When travelling during the dark season, there is a greater chance of getting lost, running out of gas, or having an accident when you cannot see the surrounding landscape and sea ice. The Sikumiut seasonal sea ice map for November to April (Fig. 10) details the locations of known recurring naggutiit (cracks), ivujuk (ridges of rough ice that are difficult to travel over), and siku saattuq aragulimaamik (areas of thin ice all year due to strong ocean currents) with supporting latitude and longitude coordinates for input into personal GPS devices. Knowing where the locations of these hazardous ice conditions is of utmost importance when travelling in the dark of $u k i u q$ and when there is poor visibility due to blowing snow. Safety and survival while travelling on the ice during the extreme cold of ukiuq is a matter of life and death, and knowing the closest areas of safe shelter identified by Sikumiut is essential (Fig. 9). The poster (Fig. 12) emphasizes the need for extra supplies for survival and to check piturnirtillugu, the phases of the moon prior to travel. For example, high tides during a new or full moon cause the expansion of cracks, thin ice areas, and the ridging of ice.

\section{Upingaksaaq (Early Spring)}

Early spring occurs between early March and late May and is the best season for sea ice travel around Mittimatalik (Fig. 3). Air temperatures are warming from daily averages of $-30.0^{\circ} \mathrm{C}$ in March to $-9.3^{\circ} \mathrm{C}$ in May (ECCC, 2020 b). Visibility is also greatly improved with daylight averaging 9 hours in early March to 24 hours in early May (Timeanddate.com, 2020). After a cold and dark winter, a greater number of Mittimatalingmiut are now travelling on the sea ice to hunt, fish, and spend time at family cabins. The Sikumiut sea ice terminology and accompanying photographs and illustrations detail the first signs of spring (Fig. 7). Nagguti will no longer refreeze in upingaksaaq and will continue to expand, now called an aajuraq (Fig. 7). The term pilagiarniq (ice bridge) describes the areas of stable ice between aajurait that are safer for travel. The terminology also describes the stages of snowmelt on the sea ice starting with small puddles called immatttinniq (Fig. 7).

The Sikumiut seasonal sea ice map for May to July (Fig. 11) details the locations of known aajurait and siku saattuq upingaat pigiarningani (more areas of thin ice starting in spring) with supporting latitude and longitude coordinates for input into personal GPS devices. The expanded thin ice areas now include locations of spring runoff from rivers and glaciers. Figure 12 emphasizes the need to wear igaak (sunglasses) to protect from snow 


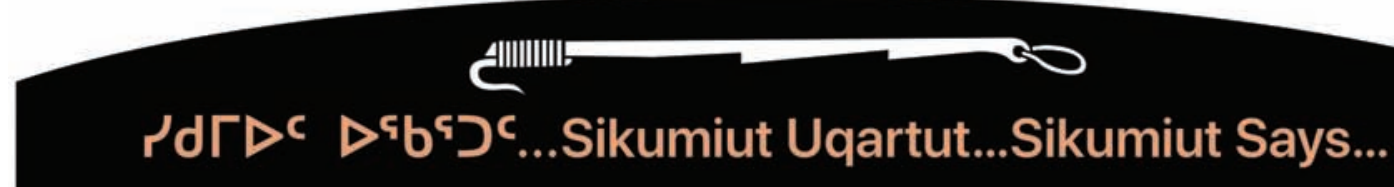

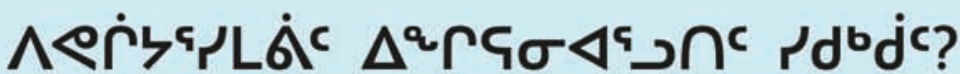 Pivagiijarsimaviit ingiraniarlutit sikukkuut? Are you prepared to travel on the sea ice?}

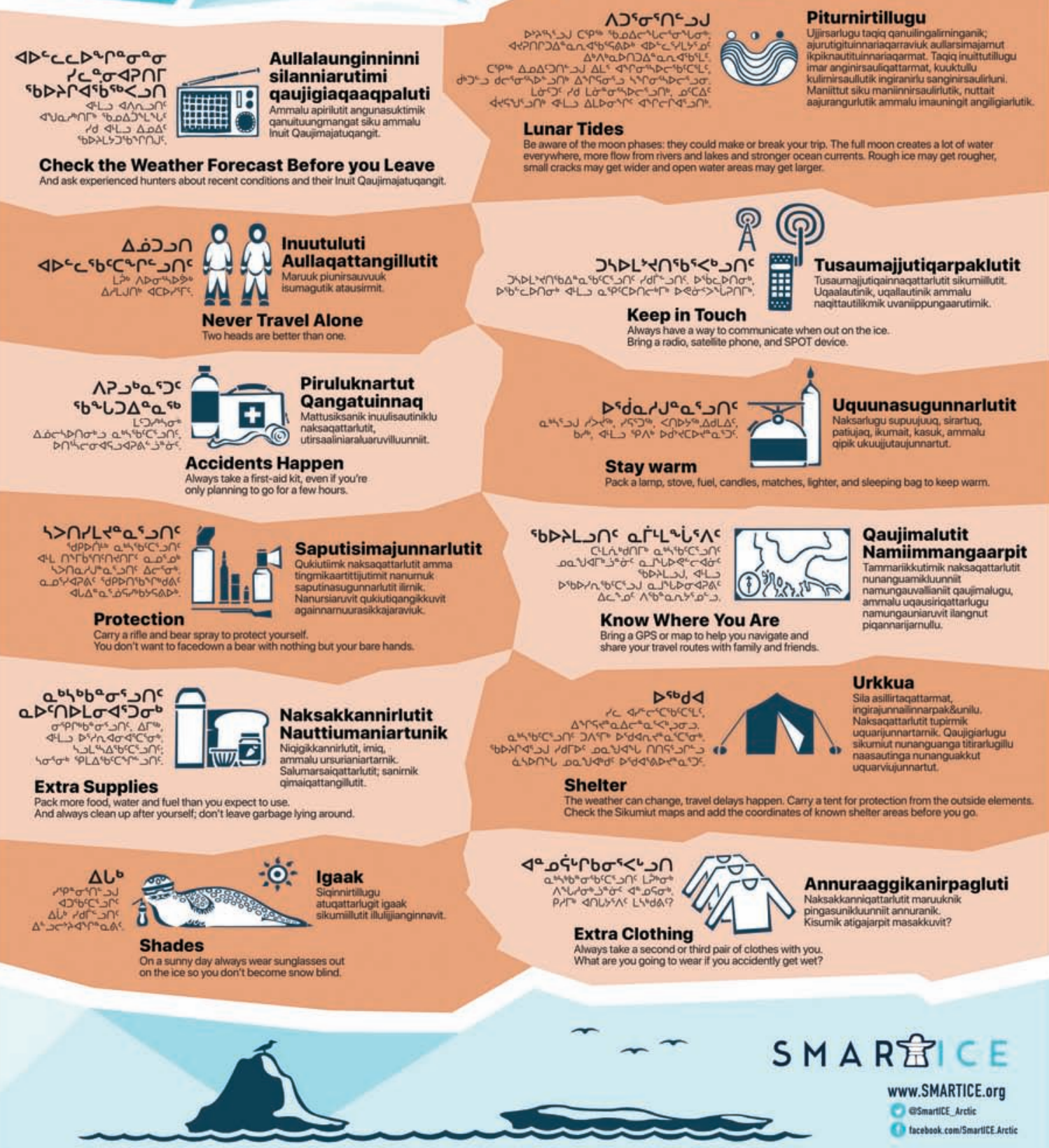

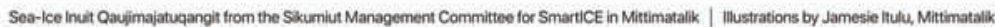




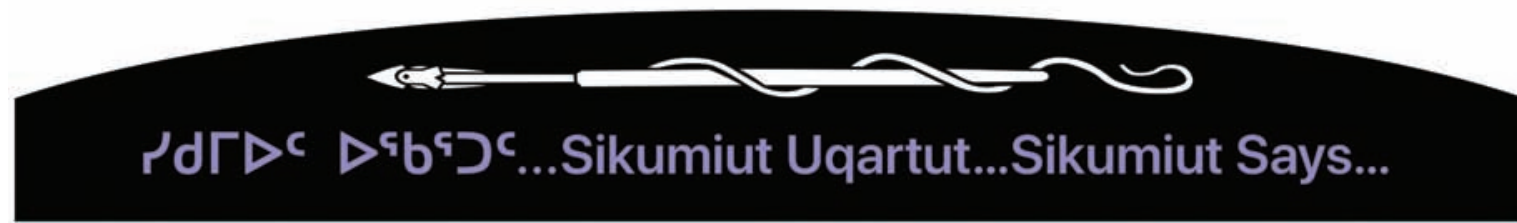

\section{'b Qaujimajariaqartut aularniaruvit sikukkuurniaruvit. What to know as you travel on the sea ice.}

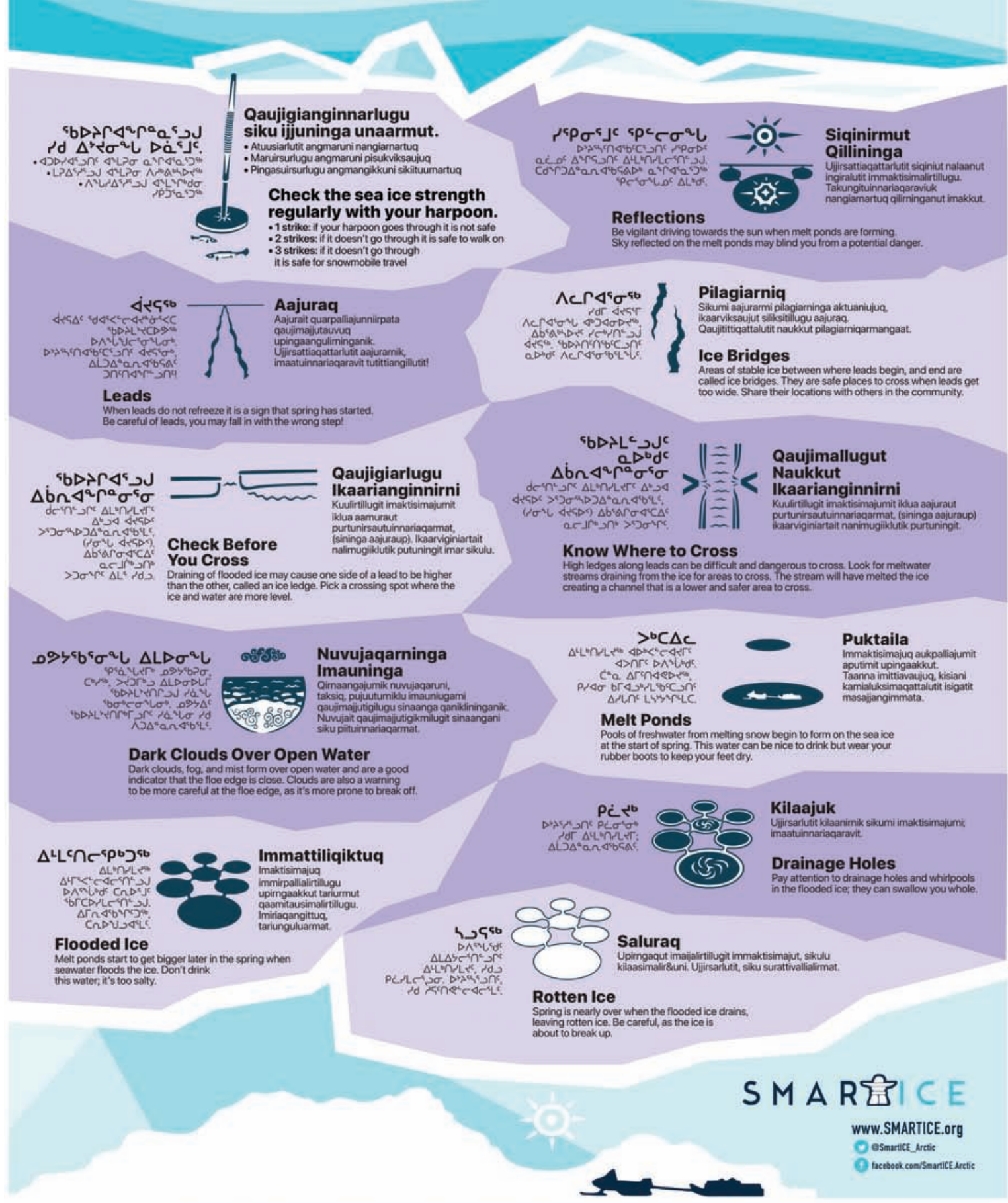


blindness during this period of 24-hour sunlight. While the temperatures and daylight are ideal for sea ice travel, aajurait are getting wider and areas of siku saattuq upingaat pigiarningani are expanding, especially with the high tides during new and full moons (piturnirtillugu). Figure 13 provides guidance for how to travel and avoid accidents on the sea ice as it is melting. For example, qaujigiarlugu ikaarianginnirni explains that if you have to cross an aajuraq, check before you cross. One side of the aajuraq may be higher than the other, and this can cause an accident if the skis on your snowmobile do not clear this ledge. Qaujimallugut naukkut ikaarianginnirni (know where to cross) explains to look for meltwater drainage on the other side of the aajuaq for areas that will be lower and safer to cross.

\section{Upingaaq (Spring)}

The air temperatures during upingaaq (Fig. 3) are normally above zero with average daily temperatures of $2.4^{\circ} \mathrm{C}$ in June and $6.6^{\circ} \mathrm{C}$ in July (ECCC, 2020b). The sea ice is now melting, and it is becoming difficult to travel due to the amount of water and slush on the sea ice. The meltwater on the sea ice is absorbing more sunlight, further accelerating sea ice melt during this period of 24-hour daylight. By early July the sea ice is starting to break up and is no longer safe to travel on. The Sikumiut sea ice terms explain how to recognize samunngaatqu, a type of ice in which your snowmobile can get stuck (Fig. 8). The terms also detail the conditions that indicate the sea ice season is coming to an end such as: kilaajuk when the meltwater is draining through the sea ice, and saluraq when the meltwater has drained from the ice and the ice is no longer safe to travel on (Fig. 8).

The poster in Figure 13 provides important information for how to travel on the sea ice during the melt period. For example, siqinirmut qillininga (reflections) describe the importance of not driving into the sun when there are melt ponds. The reflections of the sky on the melt ponds can be blinding and camouflage areas of thin ice or open water. The terminology and posters teach how to recognize melting sea ice conditions as it progresses from puktaila (snowmelt ponds) through kilaajuk (the first drainage of meltwater), to immattiliqiktuq (ice flooded by seawater) to saluraq (the last drainage of meltwater), when the ice is now rotten and about to break up (Figs. 8 and 13).

Sikumiut compiled a list of locations to display the posters and maps in the community. In May 2020 maps and posters were displayed at the Hamlet office, Hunters and Trappers Organization (HTO) office, SmartICE office, and the two grocery stores in town. Due to the Covid19 pandemic, maps and posters originally planned for the elementary and high schools, hotel, library/visitors centre, Parks Canada office, ECCC Research Station, and the Health Centre had to be postponed until spring 2021. The maps and posters are also available on the SmartICE website. Additionally, 600 copies of the terminology booklet (approximately one for each household in Mittimatalik with extra copies in spare) will be printed and distributed along with updated maps and posters for display.

\section{DISCUSSION}

Mobilizing IQ is essential for community-based adaptation for safe sea ice travel. Below we discuss how sea ice IQ teaches Inuit youth the necessary communication skills to plan for sea ice travel and identify key geographic locations while traveling on the sea ice. We also illustrate how sea ice IQ provides Mittimatalingmiut with the skills to interpret and apply supplemental information to local conditions for planning sea ice travel, and how sea ice IQ fills critical spatial and temporal gaps during sea ice travel.

\section{Sea Ice IQ Communication Skills}

Early on in project planning workshops, a Sikumiut member explained how their Inuktitut sea ice terminology is a critical communications tool for sharing information with each other. "We have a way of speaking to each other. We can say just one word and others will immediately understand the ice conditions we are talking about" (Wilson, 2017:4). The importance of learning the terminology in Inuktitut became obvious when cross-referencing terms with the English WMO standard for sea ice terminology (ECCC, 2016). Out of the 65 different Inuktitut terms recorded, there were very few equivalents in English. The English WMO terms evolved to describe sea ice areas for ships to avoid, such as thicker and higher concentrations of ice, and to target navigation through ice-free, thinner, or lower concentrations of ice. The Inuktitut terms in contrast evolved to support Inuit travel safely on the sea ice, to identify and avoid thinner areas of ice and open water, and to travel on the thicker, stable areas of ice. A few English terms are used in the Sikumiut sea ice terminology booklet, only because Sikumiut members used them; these include leads, ridges, floe edge, and melt ponds. The precision of the sea ice terms in Inuktitut is apparent in the booklet when comparing to the translated English definitions. The English definitions are much longer and require more text to explain because the English terminology did not evolve around travelling on the sea ice (Figs. 4-8).

Increasing the use of the Inuktitut sea ice terms is essential so different generations in the community can communicate with one another to make informed decisions around safe sea ice travel. Sea ice travel information is still primarily shared orally between experienced hunters over VHF radio, satellite or mobile phone, community radio, and during coffee breaks or gatherings at the HTO office. The Sikumiut seasonal maps share the locations of where ice hazards normally are, but these conditions can vary by year and season. Through this oral communication, Mittimatalingmiut can learn about current conditions from those who have recently returned from the sea ice, 
discuss travel plans, and decide on the best routes to take. Learning the Inuktitut place names is also an integral part of sharing local sea ice information. Known sea ice hazards are often identified with local place names to provide a navigational reference. The first versions of the maps included GPS positions to provide geographical references for youth (Figs. 9-11); however, Sikumiut requested that the spring 2022 versions of the maps also include local place names. Understanding the local sea ice terminology and place names is especially necessary during SAR events to ensure clear communications amongst different generations of volunteers about sea ice conditions and search locations. Terminology and place names are also critical if Mittimatalingmiut need to be rescued while out on the sea ice. Communication tools such as VHF radio and satellite and mobile phone signals are not always clear and can degrade when outside of the community. Knowing and being specific in communicating your location and the potential sea ice hazards around you are critical information to share to support your own rescue.

\section{Sea Ice IQ for Planning and During Travel}

We return to Table 1 (column 4) to discuss the currently available sources of information and their application for planning travel (white rows) and during travel (grey rows) on the sea ice. We compare and contrast this information across seasons to demonstrate how sea ice IQ is necessary to interpret this additional information for local conditions in planning travel and to fill critical spatial and temporal gaps for safety during sea ice travel (Table 1, column 5).

Sikumiut members recommend that Mittimatalingmiut check to ensure good weather conditions before they travel on the sea ice (Fig. 12). Available weather information is based on observations from the airport and two- to five-day forecasts from weather models (ECCC, 2020a). Weather information is important for planning travel, but these forecasts do not capture the scale of local weather conditions (Table 1). Once on the sea ice, the local weather can be very different and change unexpectedly. Being prepared with extra supplies and means for communication (Fig. 12) is a matter of survival on the ice when the weather suddenly changes. The maps (Figs. 9-11) are a consensus of Sikumiut's mental maps, which they use to visualize the sea ice conditions by season in order to integrate the weather information for planning travel. During travel, youth begin to develop their own mental maps to become aware of their current location on the ice, where the hazardous sea ice is in relation to their location, and the nearest locations for shelter from changing weather conditions (Figs. 9-11). Preparedness and situational awareness instill a level of confidence and critical decision-making skills needed to identify and respond to changing conditions while out on the sea ice (Aporta and Higgs, 2005; Ford et al., 2007; Pearce et al., 2010; Clark et al., 2016b).

Checking the tide tables before travelling on the sea ice is also recommended by Sikumiut (Fig. 12). Sea ice IQ teaches
Mittimatalingmiut how to interpret this tidal information for particular local sea ice features that become more hazardous during high tides when the ocean currents are stronger. For example, the terminology in Figure 6 explains how during ukiuq, naggutiit will form during high tides, but are usually narrow, will refreeze, and are generally easy to cross by snowmobile. However, in upingaksaaq, the naggutiit will no longer re-freeze and are now called aajurait. These aajurait will expand during high tides and can become too wide and dangerous to cross. The Sikumiut maps provide a seasonal and spatial baseline of sea ice features that become more hazardous during a new and full moon (i.e., siku saattuq aragulimaamik [Fig. 10] and siku saattuq upingaat pigiarningani [Fig. 11]) to integrate this tidal information for local conditions. Meteorological weather and ice offices around the world use "climate normals," which are observed conditions averaged over a 30 -year period, to provide a baseline of average or normal conditions (WMO, 2017). The Sikumiut IQ maps are Mittimatalik's sea ice climate normal maps, derived by consensus from a community perspective (Riedlinger and Berkes, 2001).

Publicly available optical true colour composite (MODIS and Sentinel-2) and synthetic aperture radar imagery (Sentinel-1) is another tool that some experienced Sikumiut members check to get an overview of sea ice conditions prior to travel (Table 1). For example, during ukiaq you can monitor the sinaa forming, which indicates that the sea ice is becoming tuvaq. In upingaksaaq and upingaaq, the satellite imagery can be used to monitor siku saattuq upingaat pigiarningani and any signs of breakup at the sinaa (Table 1). The current temporal coverage of publicly available satellite data for Mittimatalik is every 2-3 days, not frequent enough for the rapidly changing ice conditions during freeze-up and breakup. This suite of satellite imagery cannot tell you the thickness of the sea ice, and it can be difficult for untrained users to differentiate areas of smooth sea ice from open water in synthetic aperture radar imagery. Also, the resolution of publicly available satellite imagery is not detailed enough to capture sea ice hazards dangerous for snowmobile travel (Table 1). For example, the average length of a snowmobile is approximately $3 \mathrm{~m}$ and aajurait greater than $2 \mathrm{~m}$ in width would be considered dangerous to cross. Sentinel-1 imagery available on public websites (Polar View, 2019; Arctic Eider Society, 2020) can detect features greater than $100 \mathrm{~m}$, so only aajurait larger than this are visible in the imagery. The Sentinel-1 imagery can help to identify when these large aajurait open; however, for safe travel on the sea ice, Mittimatalingmiut need to know the locations of aajurait much smaller than $100 \mathrm{~m}$ that are not visible in the satellite imagery. Sikumiut's sea ice IQ fills these temporal $(2-3$ days $)$ and spatial $(<100 \mathrm{~m})$ gaps (Riedlinger and Berkes, 2001). The maps (Figs. 10 and 11) provide the locations of the known sea ice hazards by season at spatial resolutions under $100 \mathrm{~m}$, and the posters (Figs. 12 and 13) teach Inuit how to visually identify hazardous sea ice features as they travel, how to test the sea ice, and how to navigate safely across aajurait. At community meeting 
places (i.e., the HTO), experienced Mittimatalingmiut will share the locations of new sea ice hazards as they emerge throughout upingaksaak and upingaaq using their sea ice IQ and communicate this IQ over local radio.

Sea ice charts available from the CIS are another potential sea ice travel adaptation tool because they provide a synthesis and interpretation of weather and satellite data. The ice charts are developed to support marine navigation and are produced using satellite data as their main source of information (Shokr and Sinha, 2015: Chapter 11). Currently the CIS has access to more than twice daily satellite coverage of the Canadian Arctic compared to the $2-3$ days of coverage that is available publicly. The CIS charts are at spatial resolutions larger than the satellite data $(>500 \mathrm{~m})$ and therefore do not capture the spatial scales needed for sea ice travel (Table 1). In reviewing the CIS charts with Sikumiut members, they found the WMO egg code difficult to understand, and the shipping sea ice terms were very different from theirs. However, there was interest in the locations of ice edges and areas of open water in the CIS charts. For the Mittimatalik region, the CIS daily ice charts are produced after sea ice breakup in mid-July when shipping to the Mary River mine starts, and continue until freeze-up in mid to late October when the shipping season ends. The production of the CIS charts shifts from daily to weekly for the Mittimatalik region between mid-October and mid-July when the sea ice is frozen, and shipping does not occur. However, there is a short period at the margins of the shipping seasons in which some Sikumiut members thought the daily ice charts could be useful. In July, during the late stages of breakup the daily ice charts could be used to locate areas of open water so Mittimatalingmiut could begin to hunt using their boats. Again in October as the shipping season is ending, the ice charts could be used to monitor areas of open water and new ice forming to continue to hunt by boat in the early stages of sea ice freeze-up. This short 2- to 3-week time period at the beginning and end of the sea ice season seems to be the only time of the year when Inuit and marine shipping ice information needs overlap (Table 1). Experienced hunters can use the CIS charts in planning their travel, but sea ice IQ is necessary to apply this information to local conditions. Sea ice conditions during freeze-up can change by the hour, and knowledge of how wind directions and temperatures contribute to sea ice formation is essential. Sea ice IQ teaches Inuit to recognize and identify which thin ice types they can navigate their motorboats around or through and fills the necessary spatial and temporal scale information gaps as they travel during ukiaksaaq (Fig. 4).

SmartICE provides community scale $(3-10 \mathrm{~m})$ daily sea ice thickness measurements from thermistor based stationary SmartBUOYs. Ice thickness maps are produced at weekly to daily scales (frequency often increases in upingaaq) along the main Mittimatalik travel routes using an electromagnetic induction sensor towed behind a snowmobile (SmartQAMUTIK). However, the ice thickness instruments cannot be deployed until ukiuq, once the sea ice is safe for travel (Fig. 6). The Sikumiut maps fill this seasonal (temporal) gap during ukiaksaaq and ukiaq by sharing the traditionally safe sea ice trails broken by experienced Mittimtatalingmiut once the sea ice is safe enough to travel on (Fig. 9). Between ukiuq and upingaaq, Mittimatalingmiut can consult the community SmartICE information posted on Facebook and the SIKU website (Arctic Eider Society, 2020) to plan their travel. Using the SIKU app on their mobile phones, Mittimtatalingmiut can track their GPS position in relation to SmartQAMUTIK ice thickness maps. But it is the IQ reflected in the sea ice terminology (Figs. 4-8) and posters (Figs. 12, 13) that teach Inuit youth how to recognize hazards and test the sea ice thickness to fill the spatial and temporal scales needed during travel.

A tool that has been widely adapted by Inuit are GPS devices. GPS devices can provide a much-needed source of location information for orientation in low visibility (i.e., fog and darkness), when navigating new and alternative routes, and for marking the locations of hazardous sea ice conditions to share with others at community scales $(3-10 \mathrm{~m})$ (Aporta and Higgs, 2005; Gearheard et al., 2011; Christie et al., 2018; Arctic Eider Society, 2020). However, there are concerns that GPS devices give Inuit youth a false sense of security and increase risk-taking behaviour by navigating outside of established trails made by experienced hunters (Wenzel, 2004; Aporta and Higgs, 2005; Ford et al., 2008; Christie et al., 2018). Sea ice IQ teaches Inuit youth the skills to identify dangerous sea ice types as they travel (Figs. 4-8) and to understand where they are geographically on the ice (Figs. 10, 11), rather than simply travelling in the straight-line route provided by GPS devices (Aporta and Higgs, 2005; Christie et al., 2018). Sikumiut members understand that few youth have had the opportunity to learn the traditional ways of navigation. Sikumiut's decision to include GPS coordinates for areas of shelter and known hazardous ice conditions on the maps (Figs. 9-11) are to encourage youth to add these locations to their GPS devices in planning travel, so they can be more aware of them as they travel. Mobile and GPS devices can malfunction, especially in the extreme cold (batteries get cold and screens freeze) and readings misread (Aporta and Higgs, 2005; Pearce et al., 2011) (Table 1). Sikumiut's request to include important Inuktitut place names in the next version of the maps is intended to teach these important landmarks for navigation, so Mittimatalingmiut youth are not solely reliant on their GPS devices in case of a malfunction.

The white rows in Table 1, labelled " $\mathrm{P}=$ planning sea ice travel," show that a majority of these information sources are useful in different ways and at different temporal and spatial scales for planning travel, but no one tool can provide all the information needed for planning travel across all seasons. IQ allows experienced Inuit sea ice travellers with the skills and knowledge to utilize and synthesize a variety of information to make decisions in preparation for local sea ice travel. The grey rows in Table 1, labelled 
"D = during sea ice travel," show the usefulness of GPS and mobile devices, but IQ provides the skills to utilize these devices and make safe travel decisions when travelling on the sea ice.

\section{CONCLUSION}

This paper developed a novel, coproduced, crosscultural, Inuit-led research approach to support safe sea ice travel for the community of Mittimatalik. The training of Inuit youth to document and learn sea ice IQ from Sikumiut members was critical to mobilize this knowledge across generations. Our research provides a practical example that emphasizes the continued relevance of sea ice IQ. New sources provide valuable information for planning sea ice travel; however, it is the community-specific IQ that help Inuit decipher and apply this information to their local sea ice conditions. IQ is reflected in the Inuktitut sea ice terms and provides a foundation for Inuit youth to expand their sea ice communication and navigation skills. Knowing and understanding the sea ice terms provide capacity for youth to participate in group discussions with experienced hunters to learn more about current sea ice conditions for planning travel. Sea ice IQ helps Inuit youth develop the decision-making skills to identify and test the safety of sea ice and fill local spatial and temporal information gaps while travelling on the sea ice. IQ also teaches emergency preparedness skills in planning for travel and situational awareness in learning your location to avoid dangerous sea ice areas and to identify the closest areas of shelter in case of unexpected weather, accidents, or equipment failure. While these sea ice IQ products cannot replace going out with someone knowledgeable to learn and practise in context, Sikumiut's goals in producing the IQ products are to encourage and inspire more youth to start learning and practising their sea ice IQ.

\section{ACKNOWLEDGEMENTS}

Our enormous gratitude goes to all members of the Sikumiut Management Committee for their leadership and generosity: Brian Koonoo, Caleb Sangoya, Elijah Panipakoocho, David Angnatsiak, Gamalie Kilukishak, Ivan Koonoo, Jonathan Pitseolak, Moses Arnagoalik and Sheati Tagak. Thank you to Ikaarvik, Shelly Elverum, and the Inuit youth who invited SmartICE to Mittimatalik for your advice and encouragementyou have been a constant source of inspiration for this research. The workshop/meeting interpreters in this work play such a critical role in communicating and sharing knowledge, and we are truly thankful to Malachi Arreak, Morgan Arnakallak, and Abraham Kubulu (Mittimatalik and Arviat). Thank you to Mishak Allurut (Ikpiarjuk) for the timely translation of many Sikumiut documents. Thank you to Lynn Moorman from Mount Royal University and Bhavana Chaudhary from ECCC's Landscape Science and Technology for their efforts in helping develop the GIS training for the Inuit youth. We also thank Beverly Hancock for her professional assistance in the layout of the Sikumiut maps and posters and Carolann Harding with SmartICE for all her administrative support. We are grateful to ECCC's CIS for ongoing encouragement and support for this research and Evan Richardson with ECCC's Canadian Wildlife Service for use of the Mittimatalik Research Station for accommodation and meeting space. Finally, thank you to the two anonymous journal reviewers for their insightful suggestions and encouragement that helped to improve and clarify this paper.

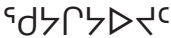

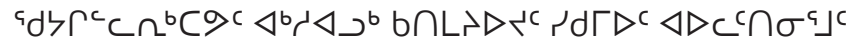

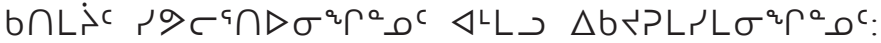
$>c \Delta \Delta^{a} d \circ^{b}, b \Delta c \wedge 4^{a} \mathrm{~b} b, \Delta c \Delta b<\sigma^{b}<d^{c} J^{b}, c \Delta a \cap$

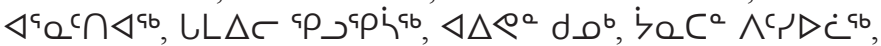
له

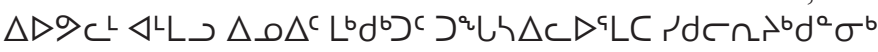

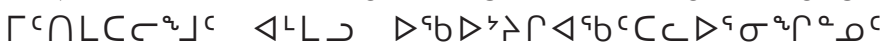

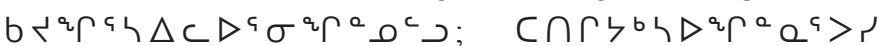

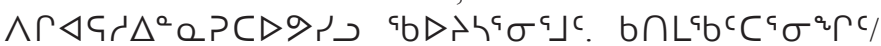

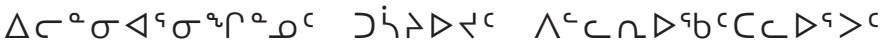

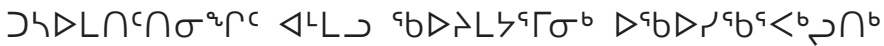

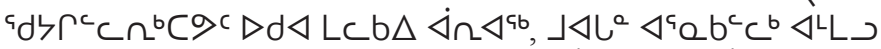

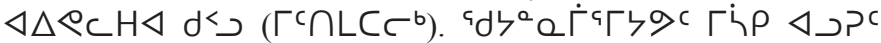

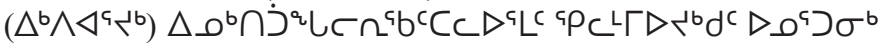

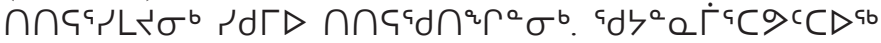

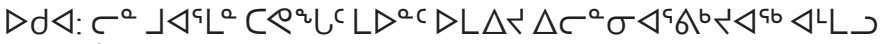

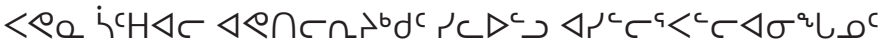

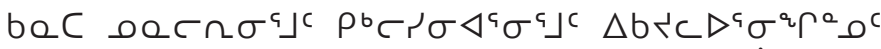

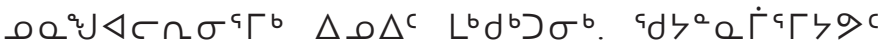

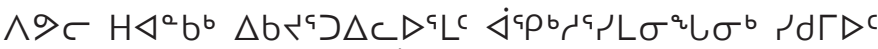

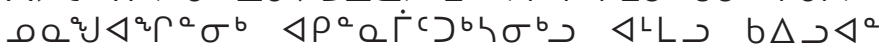

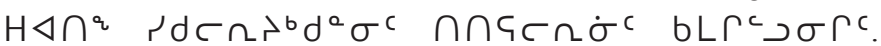

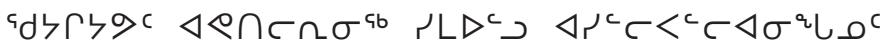

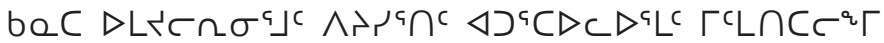

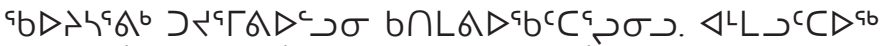

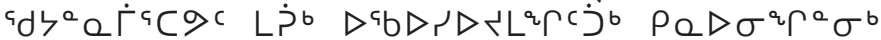

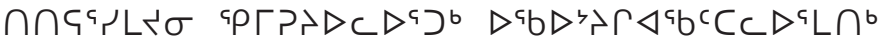

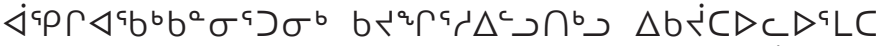

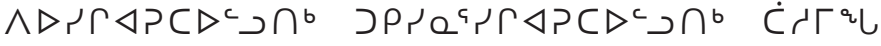

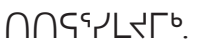

\section{FUNDING AND APPROVALS}

This research was funded in part by Public Safety Canada's Search and Rescue New Initiatives Fund, the Social Sciences and Humanities Research Council of Canada, the Northern Scientific Training Program, ArcticNet, and Polar Knowledge Canada. Thank you to SmartICE Sea ice Monitoring \& Information Inc. for all their administrative support. This research received the following approvals: Nunavut Research License \#02 013 20R-M and Memorial University of Newfoundland 
Interdisciplinary Committee on Ethics in Human Research, ethics approval \#20190684-AR.

\section{REFERENCES}

Anselmi, E. 2019. Researcher puts a dollar figure on Nunavut's country food harvest. Nunatsiaq News, December 5.

Aporta, C. 2002. Life on the ice: Understanding the codes of a changing environment. Polar Record 38(207):341 - 354 .

https://doi.org/10.1017/S0032247400018039

- 2010. The sea, the land, the coast, and the winds: Understanding Inuit sea ice use in context. In: Krupnik, I., Aporta, C., Gearheard, S., Laidler, G.J., and Holm, L.K., eds. SIKU: Knowing our ice: Documenting Inuit sea-ice knowledge and use. London: Springer. 163-180.

https://doi.org/10.1007/978-90-481-8587-0

Aporta, C., and Higgs, E. 2005. Satellite culture: Global positioning systems, Inuit wayfinding, and the need for a new account of technology. Current Anthropology 46(5):729-753. https://doi.org/10.1086/432651

Aqqiumavvik. 2020. Arviat Wellness Society: Young hunters program.

https://www.aqqiumavvik.com/young-hunters-program

Archer, L., Ford, J.D., Pearce, T., Kowal, S., Gough, W.A., and Allurut, M. 2017. Longitudinal assessment of climate vulnerability: A case study from the Canadian Arctic. Sustainability Science 12(1):15-29. https://doi.org/10.1007/s11625-016-0401-5

Arctic Eider Society. 2020. SIKU: The Indigenous knowledge social network. www.siku.org

Bell, T., Briggs, R., Bachmayer, R., and Li, S. 2014. Augmenting Inuit knowledge for safe sea-ice travel: The SmartICE information system. 2014 Oceans - St. John's:1 -9.

https://doi.org/10.1109/OCEANS.2014.7003290

Carter, N.A., Dawson, J., Joyce, J., Ogilvie, A., and Weber, M. 2018. Arctic corridors and northern voices: Governing marine transportation in the Canadian Arctic (Pond Inlet, Nunavut community report). Ottawa: University of Ottawa. https://doi.org/10.20381/RUOR37271

Carter, N.A., Dawson, J., Simonee, N., Tagalik, S., and Ljubicic, G. 2019. Lessons learned through research partnership and capacity enhancement in Inuit Nunangat. Arctic 72(4): $381-403$. https://doi.org/10.14430/arctic69507

Christie, K.S., Hollmen, T.E., Huntington, H.P., and Lovvorn, J.R. 2018. Structured decision analysis informed by traditional ecological knowledge as a tool to strengthen subsistence systems in a changing Arctic. Ecology and Society 23(4): 42. https://doi.org/10.5751/ES-10596-230442

Clark, D.G., Ford, J.D., Berrang-Ford, L., Pearce, T., Kowal, S., and Gough, W.A. 2016a. The role of environmental factors in search and rescue incidents in Nunavut, Canada. Public Health 137:44-49.

https://doi.org/10.1016/j.puhe.2016.06.003
Clark, D.G., Ford, J.D., Pearce, T., and Berrang-Ford, L. 2016b. Vulnerability to unintentional injuries associated with landuse activities and search and rescue in Nunavut, Canada. Social Science \& Medicine 169:18-26.

https://doi.org/10.1016/j.socscimed.2016.09.026

Cunsolo Willox, A., Harper, S.L., Edge, V.L., Landman, K., Houle, K., Ford, J.D., and the Rigolet Inuit Community Government. 2013. The land enriches the soul: On climatic and environmental change, affect, and emotional health and well-being in Rigolet, Nunatsiavut, Canada. Emotion, Space and Society 6(1):14-24/

https://doi.org/10.1016/j.emospa.2011.08.005

Damas, D. 2002. Arctic migrants/Arctic villagers: The transformation of Inuit settlement in the central Arctic. Montreal and Kingston: McGill-Queen's University Press. https://doi.org/10.2307/j.ctt809qt

Dawson, J., Carter, N.A., van Luijk, N., Weber, M., and Cook, A. 2020. Arctic corridors and northern voices project: Methods for community-based participatory mapping for low impact shipping corridors in Arctic Canada. MethodsX 7: 101064. https://doi.org/10.1016/j.mex.2020.101064

DFO (Department of Fisheries and Oceans Canada). 2020. Tides, currents and water levels for zone 39.

https://tides.gc.ca/eng/find/zone/39

Driscoll, D.L., Mitchell, E., Barker, R., Johnston, J.M., and Renes, S. 2016. Assessing the health effects of climate change in Alaska with community-based surveillance. Climatic Change 137:455-466. https://doi.org/10.1007/s10584-016-1687-0

Druckenmiller, M.L., Eicken, H., George, J.C., and Brower, L. 2010. Assessing the shorefast Ice: Inupiat whaling trails off Barrow, Alaska. In: Krupnik, I., Aporta, C., Gearheard, S., Laidler, G.J., and Holm, L.K., eds. SIKU: Knowing our ice: Documenting Inuit sea-ice knowledge and use. London: Springer. 203-228. https://doi.org/10.1007/978-90-481-8587-0

__ 2013. Trails to the whale: Reflections of change and choice on an Iñpiat icescape at Barrow, Alaska. Polar Geography 36(1-2):5-29.

https://doi.org/10.1080/1088937X.2012.724459

Dufour-Beauséjour, S., Wendleder, A., Gauthier, Y., Bernier, M., Poulin, J., Gilbert, V., Tuniq, J., Rouleau, A., and Roth, A. 2020. Combining TerraSAR-X and time-lapse photography for seasonal sea ice monitoring: The case of Deception Bay, Nunavik. The Cryosphere 14(5):1595-1609. https://doi.org/10.5194/tc-14-1595-2020

Durkalec, A., Furgal, C., Skinner, M.W., and Sheldon, T. 2014. Investigating environmental determinants of injury and trauma in the Canadian North. International Journal of Environmental Research and Public Health 11(2):1536-1548. https://doi.org/10.3390/ijerph110201536

2015. Climate change influences on environment as a determinant of Indigenous health: Relationships to place, sea ice, and health in an Inuit community. Social Science \& Medicine 136-137:17-26.

https://doi.org/10.1016/j.socscimed.2015.04.026 
ECCC (Environment and Climate Change Canada). 2016. Manual of ice (MANICE). Ottawa: ECCC.

https:/www.canada.ca/en/environment-climate-change/ services/weather-manuals-documentation/manice-manual-ofice.html

- 2020a. Pond Inlet, NU: Current conditions and forecast. Ottawa: ECCC.

https://weather.gc.ca/city/pages/nu-25_metric_e.html

_. 2020b. Canadian climate normals 1981-2010 station data. Ottawa: ECCC.

https://climate.weather.gc.ca/climate_normals/ results 19812010 e.html?searchType=stnName\&txtStation Name $=$ Pond + Inlet\&searchMethod $=$ contains\&txtCentralLatM in $=0 \&$ txtCentralLatSec $=0 \&$ txtCentralLongMin $=0 \&$ txtCentr alLongSec $=0 \& \operatorname{stnID}=1774 \&$ dispBack $=1$

- 2021. Sea ice in Canada: Canadian environmental sustainability indicators. Gatineau: ECCC.

https://www.canada.ca/content/dam/eccc/documents/pdf/ cesindicators/sea-ice/2021/sea-ice-en.pdf

Eicken, H. 2013. Arctic sea ice needs better forecasts. Nature 497:431-433.

https://doi.org/10.1038/497431a

Eicken, H., Lovecraft, A.L., and Druckenmiller, M.L. 2009. Seaice system services: A framework to help identify and meet information needs relevant for Arctic observing networks. Arctic 62(2):119-136. https://doi.org/10.14430/arctic126

ESA (European Space Agency). 2019. Copernicus Open Access Hub. https://scihub.copernicus.eu/dhus/\#/home

Fawcett, D., Pearce, T., Notaina, R., Ford, J.D., and Collings, P. 2018. Inuit adaptability to changing environmental conditions over an 11-year period in Ulukhaktok, Northwest Territories. Polar Record 54(2):119-132. https://doi.org/10.1017/S003224741800027X

Ford, J.D., Pearce, T., Smit, B., Wandel, J., Allurut, M., Shappa, K., Ittusujurat, H., and Qrunnut, K. 2007. Reducing vulnerability to climate change in the Arctic: The case of Nunavut, Canada. Arctic 60(2):150-166. https://doi.org/10.14430/arctic240

Ford, J.D., Pearce, T., Gilligan, J., Smit, B., and Oakes, J. 2008. Climate change and hazards associated with ice use in northern Canada. Arctic, Antarctic, and Alpine Research 40(4):647-659. https://doi.org/10.1657/1523-0430(07-040)[ford]2.0.co;2

Ford, J.D., Gough, W.A., Laidler, G.J., MacDonald, J., Irngaut, C., and Qrunnut, K. 2009. Sea ice, climate change, and community vulnerability in northern Foxe Basin, Canada. Climate Research 38(2):137-154. https://doi.org/10.3354/cr00777

Ford, J.D., Knight, M., and Pearce, T. 2013a. Assessing the 'usability' of climate change research for decision-making: A case study of the Canadian International Polar Year. Global Environmental Change 23(5):1317-1326. https://doi.org/10.1016/j.gloenvcha.2013.06.001
Ford, J.D., McDowell, G., Shirley, J., Pitre, M., Siewierski, R., Gough, W., Duerden, F., Pearce, T., Adams, P., and Statham, S. 2013b. The dynamic multiscale nature of climate change vulnerability: An Inuit harvesting example. Annals of the Association of American Geographers 103(5):1193 - 1211. https://doi.org/10.1080/00045608.2013.776880

Fox, S. 2004. When the weather is uggianaqtuq: Linking Inuit and scientific observations of recent environmental change in Nunavut, Canada. PhD thesis, University of Colorado at Boulder.

Fox, S., Qillaq, E., Angutikjuak, I., Tigullaraq, D.J., Kautuk, R., Huntington, H., Liston, G.E., and Elder, K. 2020. Connecting understandings of weather and climate: Steps towards coproduction of knowledge and collaborative environmental management in Inuit Nunangat. Arctic Science 6(3):267-278. https://doi.org/10.1139/as-2019-0010

Gearheard, S., Matumeak, W., Angutikjuaq, I., Maslanik, J., Huntington, H.P., Leavitt, J., Kagak, D.M., Tigullaraq, G., and Barry, R.G. 2006. "It's not that simple": A collaborative comparison of sea ice environments, their uses, observed changes, and adaptations in Barrow, Alaska, USA, and Clyde River, Nunavut, Canada. Ambio 35(4):203-211. https://doi.org/10.1579/0044-7447(2006)35[203:INTSAC]2.0. $\mathrm{CO} ; 2$

Gearheard, S., Aipellee, G., and O'Keefe, K. 2010. The Igliniit project: Combining Inuit knowledge and geomatics engineering to develop a new observation tool for hunters. In: Krupnik, I., Aporta, C., Gearheard, S., Laidler, G.J., and Holm, L.K., eds. SIKU: Knowing our ice: Documenting Inuit sea-ice knowledge and use. London: Springer. 181-202.

https://doi.org/10.1007/978-90-481-8587-0

Gearheard, S., Aporta, C., Aipellee, G., and O'Keefe, K. 2011. The Igliniit project: Inuit hunters document life on the trail to map and monitor Arctic change. The Canadian Geographer 55(1):42-55.

https://doi.org/10.1111/j.1541-0064.2010.00344.x

Gearheard, S.F., Holm, L.K., Huntington, H.P, Leavitt, J.M., Mahoney, A.R., and Opie, M., Oshima, T., and Sanguya, J., eds. 2013. The meaning of ice: People and sea ice in three Arctic communities. Hanover, New Hampshire: International Polar Institute Press.

George, J.C., Huntington, H.P., Brewster, K., Eicken, H., Norton, D.W., and Glenn, R. 2004. Observations on shorefast ice dynamics in Arctic Alaska and the responses of the Iñupiat hunting community. Arctic 57(4):363-374.

https://doi.org/10.14430/arctic514

Hackett, C., Furgal, C., Angnatok, D., Sheldon, T., Karpik, S., Baikie, D., Pamak, C., and Bell, T. 2016. Going off, growing strong: Building resilience of Indigenous youth. Canadian Journal of Community Mental Health 35(2):79-82. https://doi.org/10.7870/cjcmh-2016-028

Henri, D.A., Carter, N.A., Irkok, A., Nipisar, S., Emiktaut, L., Saviakjuk, B., Salliq Project Management Committee, et al. 2020. Qanuq ukua kanguit sunialiqpitigu? (What should we do with all of these geese?) Collaborative research to support wildlife co-management and Inuit self-determination. Arctic Science 6(3):173-207.

https://doi.org/10.1139/as-2019-0015 
Heyes, S.A. 2011. Cracks in the knowledge: Sea ice terms in Kangiqsualujjuaq, Nunavik. The Canadian Geographer 55(1):69-90.

https://doi.org/10.1111/j.1541-0064.2010.00346.x

ICC-Canada. 2008. The sea ice is our highway: An Inuit perspective on transportation in the Arctic. A contribution to the Arctic marine shipping assessment. Ottawa: ICC-Canada.

- 2014. The sea ice never stops: Circumpolar Inuit reflections on sea ice use and shipping in Inuit Nunaat. Ottawa: ICC-Canada.

Ilisaqsivik. 2020. Home page. https://ilisaqsivik.ca/

Ittaq Heritage and Research Centre. 2021. Kangiqtugaapik (Clyde River) weather station network: Silalirijiit project. https://www.clyderiverweather.org/

Kalluak, M. 2017. About Inuit Qaujimajatuqangit. In: Karetak, J., Tester, F., and Tagalik, S., eds. Inuit Qaujimajatuqangit: What Inuit have always known to be true. Winnipeg: Fernwood Publishing. 41-60.

Kenny, T.-A., Fillion, M., MacLean, J., Wesche, S.D., and Chan, H.M. 2018a. Calories are cheap, nutrients are expensive - The challenge of healthy living in Arctic communities. Food Policy 80:39-54. https://doi.org/10.1016/j.foodpol.2018.08.006

Kenny, T.-A., Hu, X.F., Kuhnlein, H.V., Wesche, S.D., and Chan, H.M. 2018b. Dietary sources of energy and nutrients in the contemporary diet of Inuit adults: Results from the 2007-08 Inuit Health Survey. Public Health Nutrition 21(7):1319-1331. https://doi.org/10.1017/S1368980017003810

Knight Piésold Consulting. 2015. Mary River project: Inuit knowledge study. North Bay, Ontario: Knight Piésold Consulting.

https://www.baffinland.com/_resources/document portal/2016-nirb-annual-report-for-the-mary-riverproject_2017-11-01-55.pdf

Krupnik, I. 2011. 'How many Eskimo words for ice?' Collecting Inuit sea ice terminologies in the International Polar Year 2007-2008. The Canadian Geographer 55(1):56-68. https://doi.org/10.1111/j.1541-0064.2010.00345.x

Krupnik, I., and Jolly, D., eds. 2002. The Earth is faster now: Indigenous observations of Arctic environmental change. Fairbanks, Alaska: Arctic Research Consortium of the United States.

Laidler, G.J., and Elee, P. 2008. Human geographies of sea ice: Freeze/thaw processes around Cape Dorset, Nunavut, Canada. Polar Record 44(1):51 - 76. https://doi.org/10.1017/S0032247407007061

Laidler, G.J., and Ikummaq, T. 2008. Human geographies of sea ice: Freeze/thaw processes around Igloolik, Nunavut, Canada. Polar Record 44(2):127-153. https://doi.org/10.1017/S0032247407007152

Laidler, G.J., Dialla, A., and Joamie, E. 2008. Human geographies of sea ice: Freeze/thaw processes around Pangnirtung, Nunavut, Canada. Polar Record 44(4):335-361. https://doi.org/10.1017/S003224740800750X
Laidler, G.J., Ford, J.D., Gough, W.A., Ikummaq, T., Gagnon, A.S., Kowal, S., Qrunnut, K., and Irngaut, C. 2009. Travelling and hunting in a changing Arctic: Assessing Inuit vulnerability to sea ice change in Igloolik, Nunavut. Climatic Change 94(34):363-397.

https://doi.org/10.1007/s10584-008-9512-z

Laidler, G.J., Elee, P., Ikummaq, T., Joamie, E., and Aporta, C. 2010. Mapping Inuit sea ice knowledge, use, and change in Nunavut, Canada (Cape Dorset, Igloolik, Pangnirtung). In: Krupnik, I., Aporta, C., Gearheard, S., Laidler, G.J., and Holm, L.K., eds. SIKU: Knowing our ice: Documenting Inuit sea-ice knowledge and use. London: Springer. 45-80.

https://doi.org/10.1007/978-90-481-8587-0

Laidler, G.J., Hirose, T., Kapfer, M., Ikummaq, T., Joamie, E., and Elee, P. 2011. Evaluating the Floe Edge Service: How well can SAR imagery address Inuit community concerns around sea ice change and travel safety? The Canadian Geographer 55(1):91- 107. https://doi.org/10.1111/j.1541-0064.2010.00347.x

Ljubicic, G., Okpakok, S., Robertson, S., and Mearns, R. 2018. Uqsuqtuurmiut inuita tuktumi qaujimaningit (Inuit knowledge of caribou from Gjoa Haven, Nunavut): Collaborative research contributions to co-management efforts. Polar Record 54(3):213-233.

https://doi.org/10.1017/S0032247418000372

MacDonald, J. 2018. Stories and representation: Two centuries of narrating Amitturmiut history. In: MacDonald, J., and Wachowich, N., eds. The hands' measure: Essays honouring Leah Aksaajuq Otak's contribution to Arctic science. Iqaluit: Nunavut Arctic College Media. 43-80.

Mahoney, A., and Gearheard, S. 2008. Handbook for communitybased sea ice monitoring. Special report \#14. Boulder, Colorado: National Snow and Ice Data Center.

Mahoney, A., Gearheard, S., Oshima, T., and Qillaq, T. 2009. Sea ice thickness measurements from a community-based observing network. Bulletin of the American Meteorological Society 90(3):370-377. https://doi.org/10.1175/2008BAMS2696.1

Manseau, M. 2006. Inuit knowledge online database project Auyuittuq, Sirmlik and Ukkusiksalik National Parks.

http://inuitknowledge.lecol-ck.ca/home

Meier, W.N., Stroeve, J., and Gearheard, S. 2006. Bridging perspectives from remote sensing and Inuit communities on changing sea-ice cover in the Baffin Bay region. Annals of Glaciology 44:433-438. https://doi.org/10.3189/172756406781811790

Middleton, J., Cunsolo, A., Jones-Bitton, A., Shiwak, I., Wood, M., Pollock, N., Flowers, C., and Harper, S.L. 2020. "We're people of the snow:" Weather, climate change, and Inuit mental wellness. Social Science \& Medicine 262: 113137. https://doi.org/10.1016/j.socscimed.2020.113137

NASA (National Aeronautics and Space Administration). 2019. EOSDIS (Earth Observing System Data and Information System) Worldview.

https://worldview.earthdata.nasa.gov/

Nunavut Arctic College Media. 2020. Anijaarniq: Inuit landskills and wayfinding.

https://www.anijaarniq.com/ 
Nunavut Department of Education. 2007. Inuit Qaujimajatuqangit education framework for Nunavut curriculum. Iqaluit: Nunavut Department of Education, Curriculum and School Services Division.

https://www.gov.nu.ca/sites/default/files/files/Inuit $\% 20$ Qaujimajatuqangit\%20ENG.pdf

Panikkar, B., Lemmond, B., Else, B., and Murray, M. 2018. Ice over troubled waters: Navigating the Northwest Passage using Inuit knowledge and scientific information. Climate Research 75(1):81-94.

https://doi.org/10.3354/cr01501

Pearce, T., Smit, B., Duerden, F., Ford, J.D., Goose, A., and Kataoyak, F. 2010. Inuit vulnerability and adaptive capacity to climate change in Ulukhaktok, Northwest Territories, Canada. Polar Record 46(2):157-177. https://doi.org/10.1017/S0032247409008602

Pearce, T., Wright, H., Notaina, R., Kudlak, A., Smit, B., Ford, J.D., and Furgal, C. 2011. Transmission of environmental knowledge and land skills among Inuit men in Ulukhaktok, Northwest Territories, Canada. Human Ecology 39(3):271 - 288. https://doi.org/10.1007/s10745-011-9403-1

Pearce, T., Ford, J., Cunsolo Willox, A., and Smit, B. 2015. Inuit traditional ecological knowledge (TEK), subsistence hunting and adaptation to climate change in the Canadian Arctic. Arctic 68(2):233-245. https://doi.org/10.14430/arctic4475

Polar View. 2019. Polar View: Earth observations for Polar monitoring. https://polarview.looknorthservices.com

Pulsifer, P.L., Laidler, G.J., Fraser Taylor, D.R., and Hayes, A. 2011. Towards an Indigenist data management program: Reflections on experiences developing an atlas of sea ice knowledge and use. The Canadian Geographer 55(1):108-124. https://doi.org/10.1111/j.1541-0064.2010.00348.x

QIA (Qikiqtani Inuit Association). 2014. Qikiqtani Truth Commission: The official mind of Canadian colonialism. Iqaluit: Inhabit Media Inc.

Riedlinger, D., and Berkes, F. 2001. Contributions of traditional knowledge to understanding climate change in the Canadian Arctic. Polar Record 37(203):315 - 328. https://doi.org/10.1017/S0032247400017058

Segal, R.A., Scharien, R.K., Cafarella, S., and Tedstone, A. 2020a. Characterizing winter landfast sea-ice surface roughness in the Canadian Arctic Archipelago using Sentinel-1 synthetic aperture radar and the Multi-angle Imaging SpectroRadiometer. Annals of Glaciology 61(83):284-298. https://doi.org/10.1017/aog.2020.48

Segal, R.A., Scharien, R.K., Duerden, F., and Tam, C.-L. 2020 b. The best of both worlds: Connecting remote sensing and Arctic communities for safe sea ice travel. Arctic 73(4):461-484. https://doi.org/10.14430/arctic71896

Shokr, M., and Sinha, N. 2015. Sea ice: Physics and remote sensing. Hoboken, New Jersey: John Wiley \& Sons, Inc. and American Geophysical Union. https://doi.org/10.1002/9781119028000

SmartICE. 2020. SmartICE Sea Ice Monitoring and Information Inc. https://smartice.org/ice-safety/
Statistics Canada. 2017. Census profile, 2016 census: Pond Inlet, Hamlet. Ottawa: Statistics Canada.

https://www12.statcan.gc.ca/census-recensement/2016/dp-pd/ prof/index.cfm?Lang $=\mathrm{E}$

Tester, F. 2017. Colonial challenges and recovery in the Eastern Arctic. In: Karetak, J., Tester, F., and Tagalik, S., eds. Inuit Qaujimajatuqangit: What Inuit have always known to be true. Winnipeg: Fernwood Publishing. 20-40.

Tester, F., and Kulchyski, P. 1994. Tammarniit (mistakes): Inuit relocation in the Eastern Arctic, 1939-63. Vancouver: UBC Press.

Timeanddate.com. 2020. Pond Inlet, Nunavut, Canada — Sunrise, sunset, and daylength.

https://www.timeanddate.com/sun/canada/pond-inlet

TRC (Truth and Reconciliation Commission of Canada). 2015. Canada's residential schools: The Inuit and northern experience. Final report. Montreal \& Kingston: McGillQueen's University Press.

Tremblay, M., Furgal, C., Larrivée, C., Annanack, T., Einish, N., Swappie, N., Tookalook, P., et al. 2006. Climate change in Nunavik: Access to the territory and its resources (Final Report). Kuujjuak.

https://www.researchgate.net/profile/Martin-Tremblay-2

Tremblay, M., Furgal, C., Larrivee, C., Annanack, T., Tookalook, P., Qiisik, M., Angiyou, E., Swappie, N., Savard, J.-P., and Barrett, M. 2008. Climate change in Northern Quebec: Adaptation strategies from community-based research. Arctic 61(Suppl. 1):27-34. https://doi.org/10.14430/arctic99

Wenzel, G.W. 2004. From TEK to IQ: Inuit Qaujimajatuqangit and Inuit cultural ecology. Arctic Anthropology 41(2):238-250. https://doi.org/10.1353/arc.2011.0067

Weyapuk, W., Jr., and Krupnik, I., comp. 2012. Kinikmi sigum qanuq ilitaavut, Wales Iñupiaq sea ice dictionary. Washington, D.C.: Arctic Studies Center, Smithsonian Institution.

Wilson, K.J. 2017. Sikumiut meeting minutes: September. Unpubl. Available at SmartICE Inc. with permission from Sikumiut. PO Box 23129, 8 Rowan Street, St. John's, Newfoundland and Labrador A1B 4J9.

. 2018a. Sikumiut meeting minutes: March. Unpubl. Available at SmartICE Inc. with permission from Sikumiut. PO Box 23129, 8 Rowan Street, St. John's, Newfoundland and Labrador A1B 4J9.

. 2018b. Memorial-Sikumiut research Agreement, Unpubl. Available through contact with the lead author.

Wilson, K.J., Bell, T., Arreak, A., Koonoo, B., Angnatsiak, D., and Ljubicic, G.J. 2020. Changing the role of non-Indigenous research partners in practice to support Inuit self-determination in research. Arctic Science 6(3):127-153.

https://doi.org/10.1139/as-2019-0021

Windyty. 2020. Windy: Wind map and weather forecast. www.windy.com

WMO. (World Meteorological Organization). 2017. WMO Guidelines on the calculation of climate normal. WMO-No. 1203. Geneva: WMO.

https://library.wmo.int/doc_num.php?explnum_id=4166 